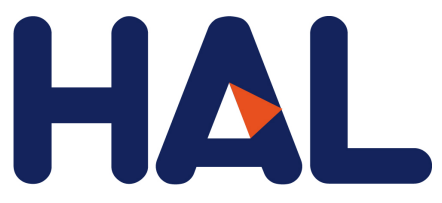

archives-ouvertes

\title{
New desulfured troglitazone derivatives: Improved synthesis and biological evaluation
}

Dorian Dupommier, Claire Muller, Corinne Comoy, Sabine Mazerbourg, Andrea Bordessa, Eline Piquard, Manon Pawlak, Flavian Piquard, Hélène Martin, Elia de Fays, et al.

\section{To cite this version:}

Dorian Dupommier, Claire Muller, Corinne Comoy, Sabine Mazerbourg, Andrea Bordessa, et al.. New desulfured troglitazone derivatives: Improved synthesis and biological evaluation. European Journal of Medicinal Chemistry, Elsevier, In press, pp.111939. 10.1016/j.ejmech.2019.111939 . hal-02421051

\section{HAL Id: hal-02421051 \\ https://hal.univ-lorraine.fr/hal-02421051}

Submitted on 20 Dec 2019

HAL is a multi-disciplinary open access archive for the deposit and dissemination of scientific research documents, whether they are published or not. The documents may come from teaching and research institutions in France or abroad, or from public or private research centers.
L'archive ouverte pluridisciplinaire HAL, est destinée au dépôt et à la diffusion de documents scientifiques de niveau recherche, publiés ou non, émanant des établissements d'enseignement et de recherche français ou étrangers, des laboratoires publics ou privés. 
<smiles>Cc1c(C)c2c(c(C)c1O)CCC(C)(COc1ccc(CC3SC(=O)NC3=O)cc1)O2</smiles>

Troglitazone (TGZ)

$I_{50}(M D A-M B-231): 45.5 \pm 3.7 \mu \mathrm{M}$

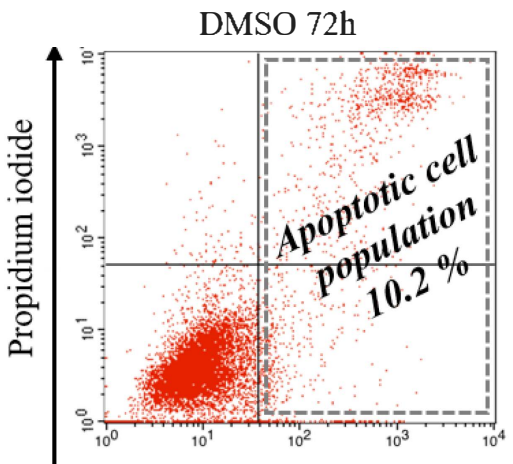

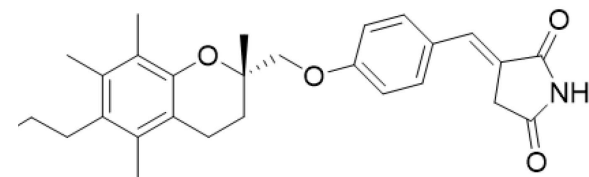

(S)-Compound 10

$I_{50}$ (MDA-MB-231): $2.7 \pm 0.4 \mu \mathrm{M}$

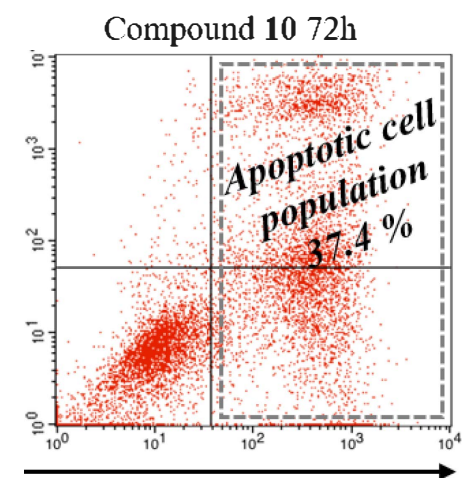

FITC-Annexin V 
New desulfured troglitazone derivatives: improved synthesis and biological evaluation

Dorian Dupommier ${ }^{\mathrm{a}, 1}$, Claire Muller ${ }^{\mathrm{b}, 1}$, Corinne Comoy ${ }^{\mathrm{a}}$, Sabine Mazerbourg ${ }^{\mathrm{b}}$, Andrea Bordessa $^{a}$, Eline Piquard ${ }^{\mathrm{a}}$, Manon Pawlak ${ }^{\mathrm{a}}$, Flavian Piquard ${ }^{\mathrm{a}}$, Hélène Martin ${ }^{\mathrm{c}}$, Elia De Fays ${ }^{\mathrm{b}}$, Stéphanie Grandemange ${ }^{\mathrm{b}}$, Stéphane Flament ${ }^{\mathrm{b}}$, Michel Boisbrun ${ }^{\mathrm{a}^{*}}$

"Corresponding author. Tel.: +33 3727452 64;

E-mail address: michel.boisbrun@ univ-lorraine.fr (M. Boisbrun).

${ }^{1}$ These authors contributed equally to the work. 
${ }^{\mathrm{a}}$ Université de Lorraine, CNRS, L2CM, F-54000 Nancy, France

${ }^{\mathrm{b}}$ Université de Lorraine, CNRS, CRAN, F-54000 Nancy, France

${ }^{\mathrm{c}}$ PEPITE EA4267, Univ. Bourgogne Franche-Comté, F-25000 Besançon, France

\begin{abstract}
Breast cancer is a major medical threat which cannot be sufficiently addressed by current therapies because of spontaneous or acquired treatment resistance. Besides, triple-negative breast cancer (TNBC) tumors do not respond to targeted therapies, thus new therapeutic strategies are needed. In this context, we designed and prepared new desulfured troglitazone (TGZ)-derived molecules and evaluated them in vitro for their anti-proliferative activity, with a special focus on triple-negative breast cancer cell lines. Optimization of the synthetic strategies and deracemization of the lead compound were performed to give highly active compound 10 with low-micromolar potency. Further studies revealed that this compound triggers apoptosis rather than cell cycle arrest as observed with TGZ.
\end{abstract}

Keywords: Troglitazone, Chromane, Deracemization, Lipase, Breast cancer, Apoptosis

\title{
1. Introduction
}

Breast cancer is the most commonly diagnosed cancer and the leading cause of cancer death in women worldwide [1]. Current treatments for breast cancer are multimodal with surgery, radiotherapy, chemotherapy, and targeted therapy [2]. However, all types of breast cancers develop resistance to these conventional therapies. A tumor could be resistant to multiple treatment strategies, such as chemotherapy and targeted therapy based on monoclonal antibody treatment [3-5]. Besides, the triple-negative breast cancer tumors (TNBCs), characterized by a lack of expression of estrogen receptor, progesterone receptor, and human epidermal growth factor receptor HER2, do not respond to targeted therapies. They further present a higher chance of recurrence after treatment with conventional chemotherapeutic agents. TNBCs (15\% of breast cancer cases worldwide) are a heterogeneous group of higher grade cancer, with the worst prognosis, compared to other breast cancer subtypes [6]. The increasing prevalence of drug resistant cancers and the limited treatment efficacy for TNBCs are strong arguments for the search for new therapeutic agents and optimized therapeutic strategies. In this context, thiazolidine-2,4-diones (TZDs) are studied in order to develop alternative or complementary anticancer agents towards breast cancers. Compounds bearing this moiety were recently proved to be of high interest as they exhibited numerous biological activities [7-11] and many of them showed promising in vitro and in vivo anticancerous properties. In particular, our team developed [12-14] Structure-Activity Relationships (SAR) studies starting from the structure of troglitazone (TGZ) (Figure 1), a molecule formerly used as an antidiabetic. We showed that some structural features both increased the antiproliferative activity toward breast cancer cell lines and decreased the toxicity against primary cultured non-malignant human hepatocytes. These aspects comprised mainly the introduction 
of a double bond adjacent to the TZD moiety (yielding $\triangle 2-T G Z$, Figure 1), and the presence of a lipophilic group on the 6-position of the chromane moiety. Meanwhile, Saha and coworkers $[15,16]$ synthesized some analogs of well-known TZDs such as rosiglitazone (RGZ), pioglitazone (PGZ), and troglitazone (TGZ) which were all used as antidiabetics, due to their affinity for the PPAR- $\gamma$ receptor. These new compounds were devoid of the sulfur atom in the TZD ring, yielding pyrrolidinedione derivatives. These compounds showed diminished PPAR- $\gamma$ binding, but also a lower toxicity toward THLE- 2 model of primary normal liver cells. Furthermore, they showed enhanced anti-cancer properties; in particular, a desulfured analog of TGZ called trosuccinimide (TSN) was promising.

The aim of the present study was to investigate a possible synergistic effect between the desulfuration and our previous SAR studies on the anti-cancer properties of the molecules. Thus, we prepared new desulfured TGZ derivatives bearing or not a double bond adjacent to the TZD moiety, and a lipophilic group (Boc or alkyl chain) at the 6-position of the chromane heterocycle. The inhibition of proliferation of breast cancer cell lines was studied, with a special attention toward cell lines derived from TNBCs, and the impact on cell cycle was also studied. Furthermore, since the chromane moiety of TGZ bears an asymmetric center, we set up a deracemization procedure in order to evaluate the influence of stereochemistry on the activity. Finally, we investigated a vectorization approach in order to still increase the potency of our molecules.
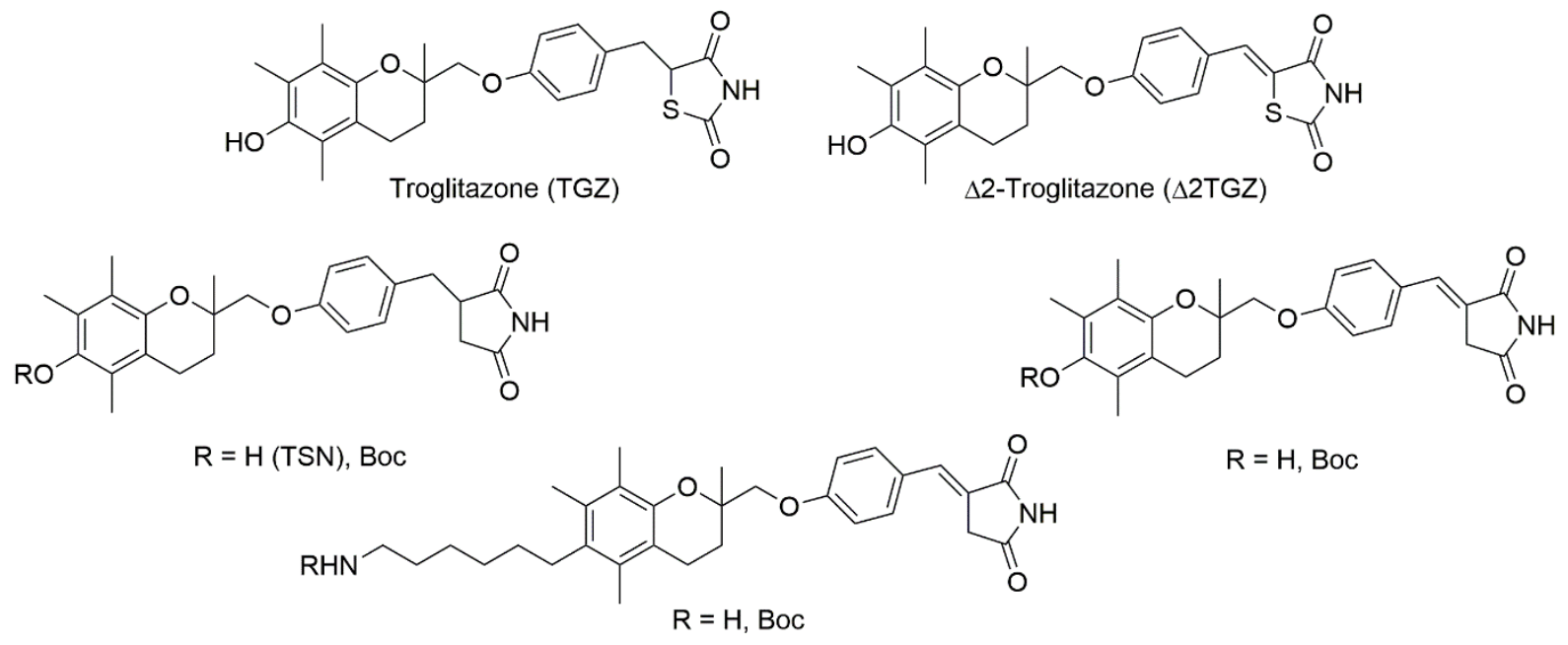

Fig. 1. Structures of troglitazone, $\Delta 2$-troglitazone, and target desulfured molecules

\section{Chemistry}

In order to prepare the envisioned desulfured troglitazone derivatives, we decided not to follow the global procedure reported by Saha and coworkers [15], as it was hampered by two very low-yield steps. Indeed, we protected the phenol function of the chromane heterocycle by a Boc group which is very easy to introduce and to remove, compared to the allyl group. Thus, we easily prepared aldehyde 1 using our reported procedure [12] (Scheme 1). It was then reacted with 3-(triphenylphosphoranylidene)pyrrolidine-2,5-dione 2 [15] to give Bocprotected desulfured analog of $\triangle 2$-TGZ 3 in good yield. Acidic treatment easily afforded the deprotected counterpart $\mathbf{4}$ which we could name $\Delta 2$-TSN. Both 3 and $\mathbf{4}$ could be reduced by hydrogenation to give saturated compounds 5 and $\mathbf{6}$ (TSN) in good yield. 
<smiles>[R6]c1c(C)c(C)c2c(c1C)CCC(C)(COc1ccc(/C=C3\CC(=O)NC3=O)cc1)O2</smiles><smiles>[R]NCCCCCCc1c(C)c(C)c2c(c1C)CCC(C)(COc1ccc(C=C3NC(=O)CC3=[R]([R])[H])cc1)O2</smiles>

Scheme 1. Reagents and conditions: (a) MeOH, RT; (b) TFA, $\mathrm{CH}_{2} \mathrm{Cl}_{2}$; (c) $\mathrm{H}_{2}$, $\mathrm{Pd} / \mathrm{C}$, EtOAc; (d) $\mathrm{Tf}_{2} \mathrm{O}$, Pyr., $\mathrm{CH}_{2} \mathrm{Cl}_{2}$, then 4-hydroxybenzaldehyde, $\mathrm{Cs}_{2} \mathrm{CO}_{3}$, DMF; (e) $\mathrm{HCl}$ gas, $\mathrm{CH}_{2} \mathrm{Cl}_{2}$.

We reported [13] that the introduction of an aminoalkyl group linked to the chromane moiety is even more effective than a Boc group in increasing the anti-proliferative activity. Thus, we prepared alcohol 7 [13] (Scheme 1) and after activation as a triflate, we reacted it with 4hydroxybenzaldehyde, giving aldehyde $\mathbf{8}$. To improve this reported procedure, the latter step was done in the presence of cesium carbonate instead of previously used potassium carbonate. In these conditions, the reaction was complete after $24 \mathrm{~h}$ instead of $48 \mathrm{~h}$. Compound 8 was then reacted with $\mathbf{2}$ as above to give $\mathbf{9}$, which was further $N$-deprotected to afford $\mathbf{1 0 .}$ Performing nuclear Overhauser enhancement measurements between the methylene protons of the pyrrolidinedione ring and the phenyl protons of compound 9 showed a $5 \%$ enhancement of the signal, confirming the $(E)$ stereochemistry of the double bond. As compounds $\mathbf{9}$ and $\mathbf{1 0}$ gave interesting biological results (see later), we intended to go further with them. Thus, we had to scale up the synthesis and the preparation of 7 [13] had to be reinvestigated (Scheme 2). 


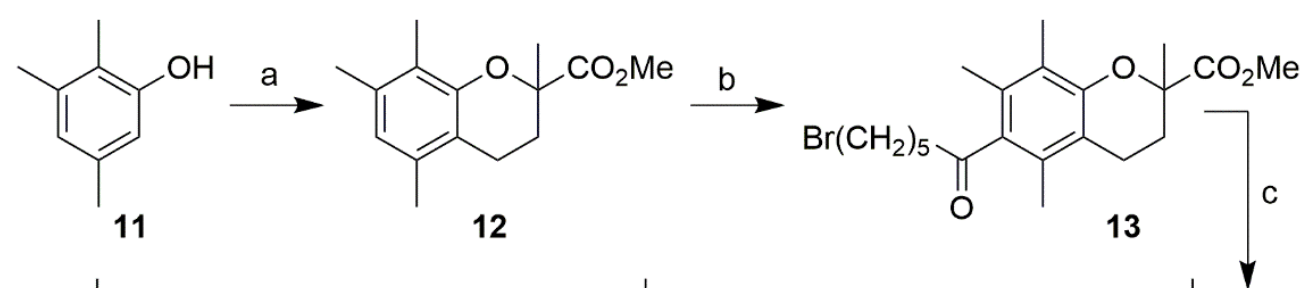<smiles>Cc1c(C)c(C)c2c(c1C)CCC(C)(CO)O2</smiles>

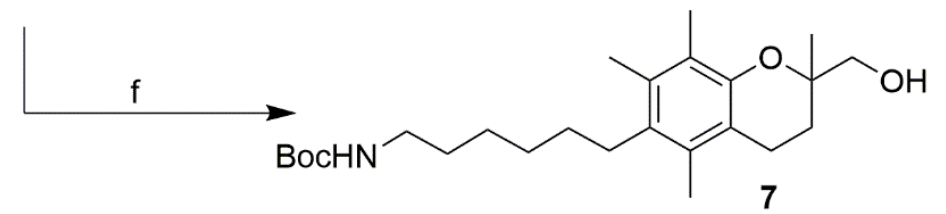

Scheme 2. Reagents and conditions: (a) (HCHO), methyl methacrylate, $\mathrm{AcOH}, \mathrm{Bu}_{2} \mathrm{NH}$; (b) $\mathrm{Br}\left(\mathrm{CH}_{2}\right)_{5} \mathrm{COCl}$, $\mathrm{AlCl}_{3}, \mathrm{CH}_{2} \mathrm{Cl}_{2}$; (c) $\mathrm{LiAlH}_{4}, \mathrm{AlCl}_{3}, \mathrm{Et}_{2} \mathrm{O}$; (d) $\mathrm{NaN}_{3}$, DMF; (e) $\mathrm{H}_{2}$, Pd/C, EtOAc; (f) Boc $\mathrm{B}_{2}, \mathrm{CH}_{2} \mathrm{Cl}_{2}$.

First, we intended to prepare easily chromane 12. Instead of achieving a three-steps procedure [12] starting from commercial trolox, we applied a reported procedure [17] on 2,3,5trimethylphenol by condensing it with methylmethacrylate and paraformaldehyde. This method afforded 12 in modest (42\%) yield, but it was straightforward since after refluxing, a simple filtration afforded a pure compound. Furthermore, as all the starting materials were affordable and since this reaction was easily scalable, huge quantities (up to $19 \mathrm{~g}$ ) of the desired compound could be obtained per batch. Besides, when we had to prepare compound $\mathbf{1 3}$ at the multi-gram scale following our reported procedure [13], it was difficult to isolate it in sufficient purity. Some by-products were generated and among them, low amounts of the sulfide 17 (Figure 2) could be identified by mass spectrometry. Its formation might be due to a reaction of $\mathbf{1 2}$ with remaining traces of highly electrophilic thionyl chloride in the freshly prepared bromohexanoyl chloride. A previous study already described the obtaining of a sulfide from a reaction between thionyl chloride and an aromatic compound [18]. In addition, traces of dimer 18 (Figure 2) were also identified by the same technique. As 17 exhibits a polarity close to the desired compound $\mathbf{1 3}$, it was difficult to remove it by chromatography.

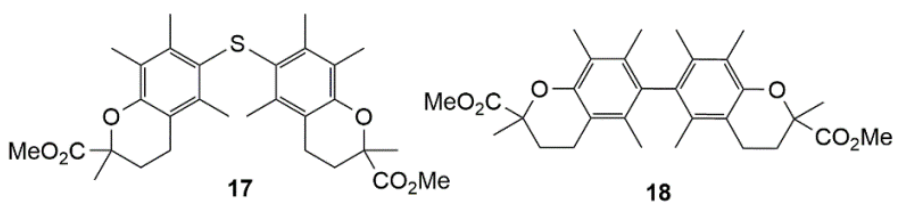

Fig. 2. Structures of by-products 17 and 18 obtained during the Friedel-Crafts reaction.

Thus, in order to avoid such side-products formation, we developed a meticulous workup. Indeed, after careful evaporation of the excess of thionyl chloride, the crude bromohexanoyl chloride was treated with formic acid in order to remove any trace of remaining reactant (see experimental section). The isolation of pure $\mathbf{1 3}$ was thus achieved at $6 \mathrm{~g}$ scale. Reduction to give $\mathbf{1 4}$ and formation of azide $\mathbf{1 5}$ proceeded as previously reported [13], but again in order to scale up the whole procedure, we had to change our protocol for the final steps. Indeed, onepot reduction of azide $\mathbf{1 5}$ and protection to give $\mathbf{7}$ gave tedious results at more than $500 \mathrm{mg}$ scale. Some non-isolated by-products were generated at the hydrogenation step; thus the 
primary amine 16 could preferentially be chromatographied before protecting it to give multigram amounts of 7 with high purity.

Since the chromane moiety contains an asymmetric carbon, it was challenging to separate both enantiomers of our lead structures in the search for a difference in anti-proliferative activity. In our hands, chiral chromatography failed to separate both isomers of either compound 9 or 10. Thus, we intended to separate them by a kinetic resolution method. Hyatt and Skelton reported [19] on the separation of both enantiomers of $(R, S)$-6-hydroxy-2,5,7,8tetramethyl-2-chromanmethanol through a succinic anhydride acylation catalyzed by supported Amano lipase PS. Thereby, we applied this technique to racemic alcohol 7, considering that the protected aminoalkyl chain should not interfere with the acylation reaction which would take place at the other side of the heterocycle. Indeed, after 18 hours of reaction and according to TLC, approximately half of 7 was converted to the expected acidester 19, together with remaining 7 (Scheme 3). Unlike Hyatt's work, the acid-ester 19 was too lipophilic to be isolated by aqueous basic extraction, nevertheless both compounds were easily separated by column chromatography. Subsequently, 19 was saponified to give the expected alcohol. According to Hyatt and Skelton work, we assume that the stereoselection should be identical, thus the lipase should preferentially catalyze the acylation of the $(S)$ isomer of 7, giving $(\boldsymbol{S})$-19 (Scheme 3). In addition, the same stereoselection was observed by others using very similar but different substrates $[17,20]$.

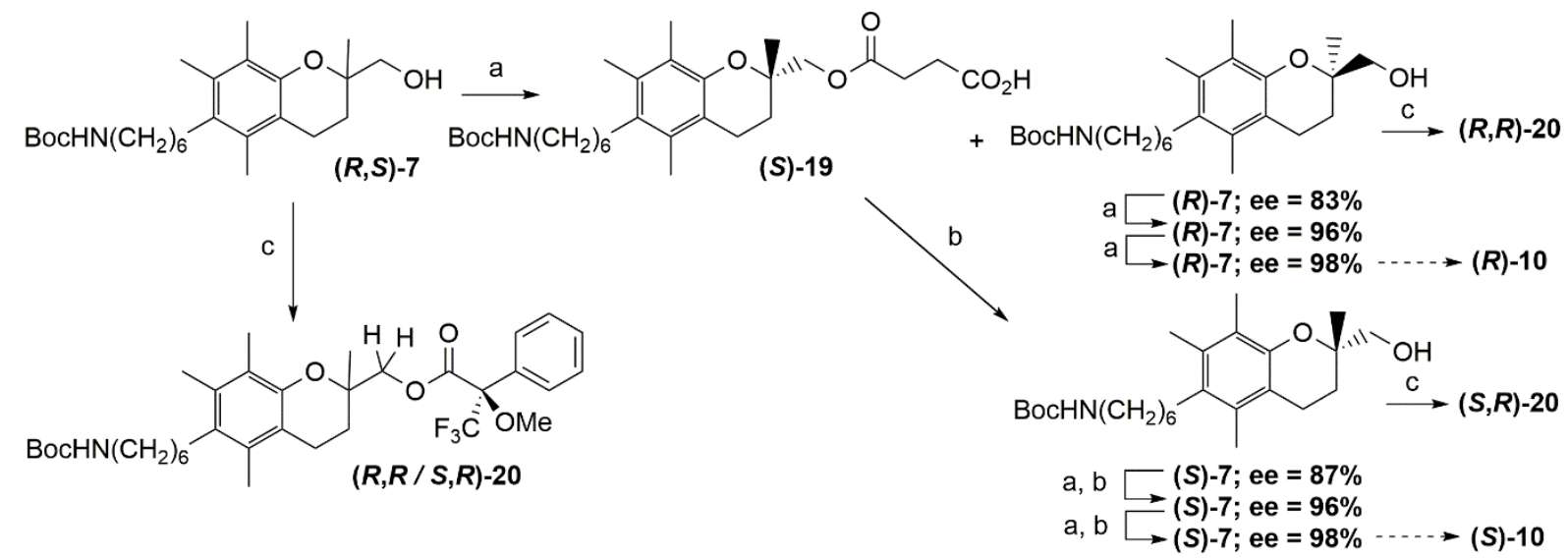

Scheme 3. Reagents and conditions: (a) Succinic anhydride, supported Amano Lipase PS, MTBE; (b) LiOH, THF/MeOH; (c) (R)-Mosher acyl chloride, $\mathrm{CDCl}_{3}, \mathrm{C}_{5} \mathrm{D}_{5} \mathrm{~N}, \mathrm{C}_{6} \mathrm{D}_{6}$.

The enantiomeric excess of $(\boldsymbol{R})-7$ and $(S)-7$ were evaluated by coupling these compounds with $(R)$-Mosher acyl chloride as reported [20] (Scheme 3) to give the corresponding esters $(\boldsymbol{R}, \boldsymbol{R})$-20 and $(\boldsymbol{S}, \boldsymbol{R})$-20 (Scheme 3, Figure 3). The relative amounts of the resulting diastereomers were evaluated by ${ }^{1} \mathrm{H}$ NMR, since each oxymethylene group gave an AB system between 4.00 and $4.35 \mathrm{ppm}$, without overlapping with any other signals. After one lipase reaction, the deduced ee was $83 \%$ in one case and $87 \%$ for the other case. It reached 96\% after two reactions for both isomers, and 98\% after three reactions (Figure 3).

Compounds $(\boldsymbol{R})-\mathbf{7}$ and $(\boldsymbol{S})-\mathbf{7}$ with $98 \%$ ee were subsequently used as substrates for a 3 -steps synthesis leading to $(\boldsymbol{R}) \mathbf{- 1 0}$ and $(\boldsymbol{S}) \mathbf{- 1 0}$ as described before. We payed attention to the possibility of racemization of the chiral carbon atom during the final acidic deprotection leading to the desired final compounds. We first examined the stability of the stereochemistry of compound $(\boldsymbol{S})-7$ in acidic conditions. In a first attempt, we noticed that it led to partial decomposition. We thus easily acetylated $(\boldsymbol{S})-\mathbf{7}$ and then deprotected it with $\mathrm{HCl}$ to give the 

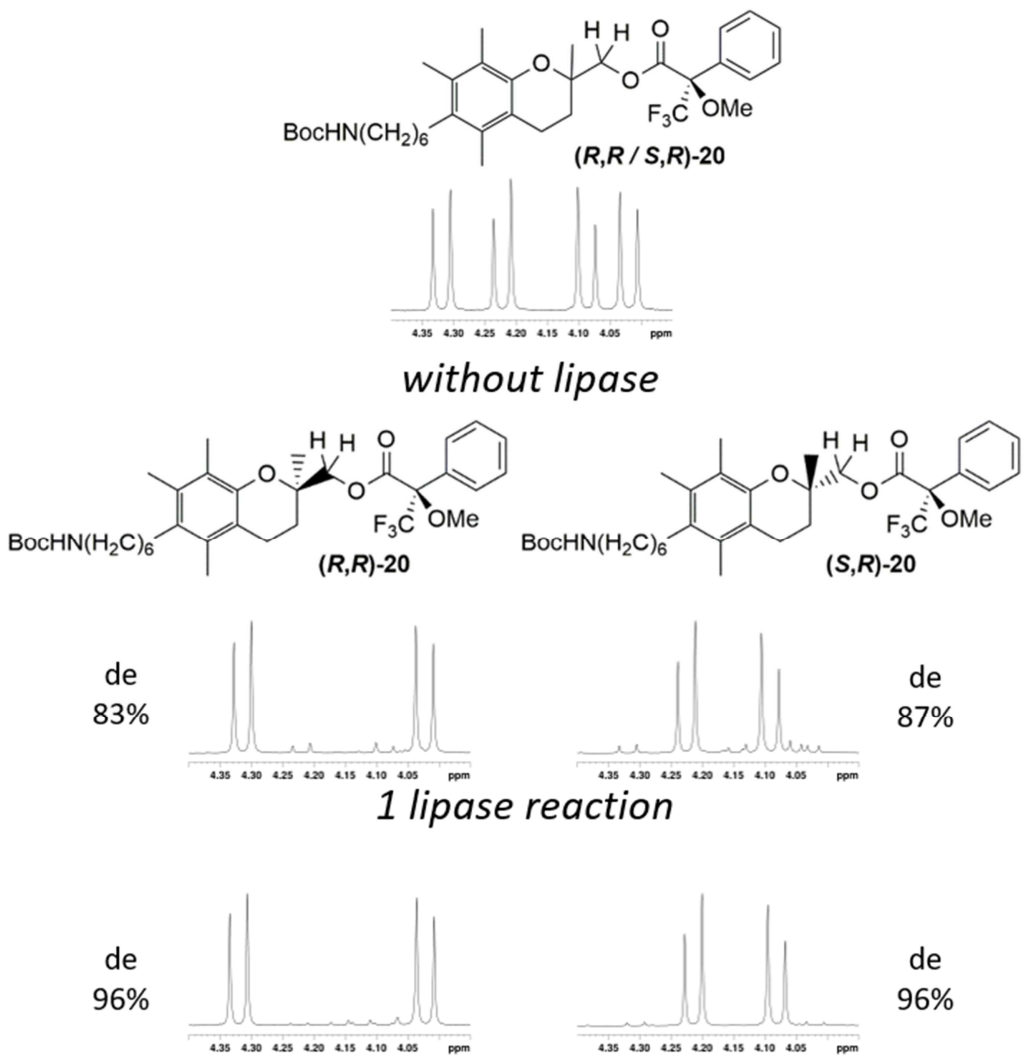

2 lipase reactions

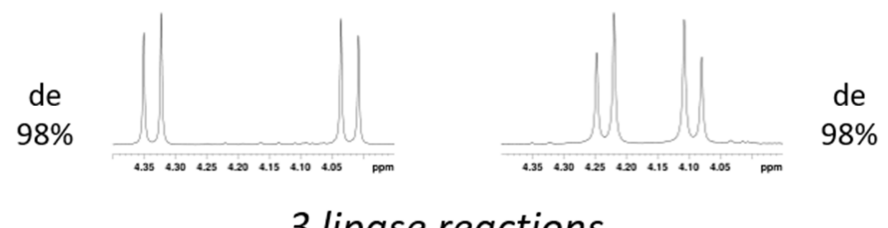

3 lipase reactions

Fig. 3. Parts of NMR spectra (400MHz, 4.00-4.35 ppm range) showing the AB system of the oxomethylene group of ester $\mathbf{2 0}$ obtained from $\mathbf{7}$ as a racemic or after one, two, and three kinetic resolution reactions.

primary ammonium chloride $(\boldsymbol{S})-\mathbf{2 1}$ (Scheme 4). It was then re-protected and deacetylated to give back the starting compound. The latter was coupled with Mosher acyl chloride as previously and the deduced ee was the same than the starting material one. Furthermore, it was also comforting that $(\boldsymbol{R})-\mathbf{1 0}$ and $(\boldsymbol{S})$-10 obtained from $(\boldsymbol{R})-\mathbf{7}$ and $(S)-\mathbf{7}$ exhibited opposite optical rotation (see experimental part).

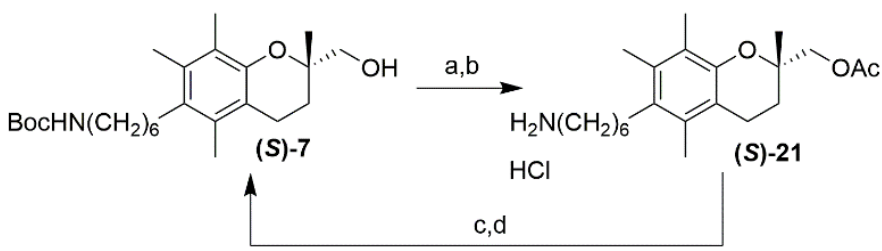

Scheme 4. Reagents and conditions: (a) $\mathrm{Ac}_{2} \mathrm{O}$, Pyr., DMAP, $\mathrm{CH}_{2} \mathrm{Cl}_{2}$; (b) $\mathrm{HCl}$ gas, $\mathrm{CH}_{2} \mathrm{Cl}_{2}$; (c) $\mathrm{Boc}_{2} \mathrm{O}, \mathrm{TEA}$, $\mathrm{CH}_{2} \mathrm{Cl}_{2}$; (d) LiOH, THF/MeOH.

With the aim of confirming the attributed stereochemistry, we did many attempts in order to get suitable crystals for X-ray diffraction. Since ferrocenyl esters were reported to facilitate the formation of crystals from carboxylic acids [21], ester $\mathbf{2 2}$ was prepared from racemic 
compound 7, but unfortunately it showed no tendency to give crystals, and acidic removal of the protecting group resulted in decomposition of the structure (Scheme 5). As we had success in getting crystals from dinitrophenylhydrazones [22], we condensed aldehyde $(\boldsymbol{R})$-8 with 2,4dinitrophenylhydrazine to give hydrazone $(\boldsymbol{R})-\mathbf{2 3}$ in good yield, which could be deprotected to give $(\boldsymbol{R})$-24. Besides, compound $(\boldsymbol{R})-\mathbf{7}$ was converted to benzoate $(\boldsymbol{R})-\mathbf{2 5}$ which was further $N$-deprotected to give $(\boldsymbol{R})-\mathbf{2 6}$ (Scheme 5). Among these compounds, $(\boldsymbol{R})$-23 and $(\boldsymbol{R})$-26 gave crystals which were submitted to X-ray analysis. For both crystals, diffraction was observed, but with a too-low resolution to be resolved.

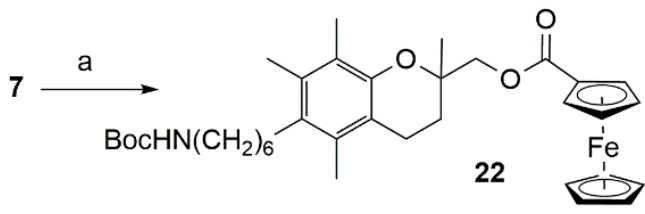<smiles>CCCCNCc1c(C)c(C)c(C)c2c1O[C@H](COc1ccc(/C=N/Nc3ccc([N+](=O)[O-])cc3[N+](=O)[O-])cc1)CC2</smiles>

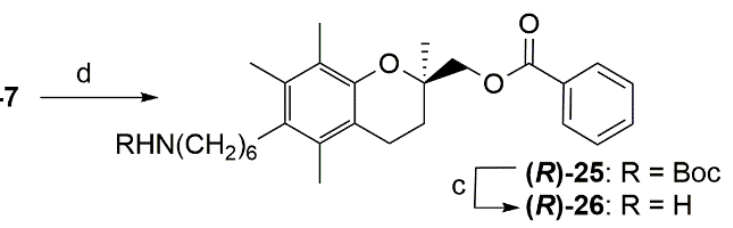

Scheme 5. Reagents and conditions: (a) Ferrocenoyl chloride, $i \mathrm{Pr}_{2} \mathrm{NEt}$, DMAP, $\mathrm{CH}_{2} \mathrm{Cl}_{2}$; (b) 2,4dinitrophenylhydrazine, MS $4 \AA$, toluene; (c) $\mathrm{HCl}$ gas, $\mathrm{CH}_{2} \mathrm{Cl}_{2}$; (d) Benzoyl chloride, pyridine, $\mathrm{CH}_{2} \mathrm{Cl}_{2}$.

Besides, we intended to vectorize our lead compound toward cancerous cells by grafting a glucose unit. For this purpose, we envisioned a copper-mediated Huisgen click reaction between an alkyne-derived glucose and an analog of $\mathbf{1 0}$ bearing an azide function. Thus, azide 15 was coupled to 4-hydroxybenzaldehyde to give aldehyde 27, which was in turn reacted with phosphoranylidene 2 to give compound 28 (Scheme 6). D-glucose was peracetylated as previously reported [23] to give $\beta$-D-glucopyranose pentaacetate which was reacted with propargyl alcohol to give 29 as described by Murray [24]. Cycloaddition reaction between 28 and 29 was conducted in the presence of in situ generated $\mathrm{Cu}(\mathrm{I})$ to give adduct 30, which could be deacetylated to give target compound $\mathbf{3 1}$ in good yield (Scheme 6).

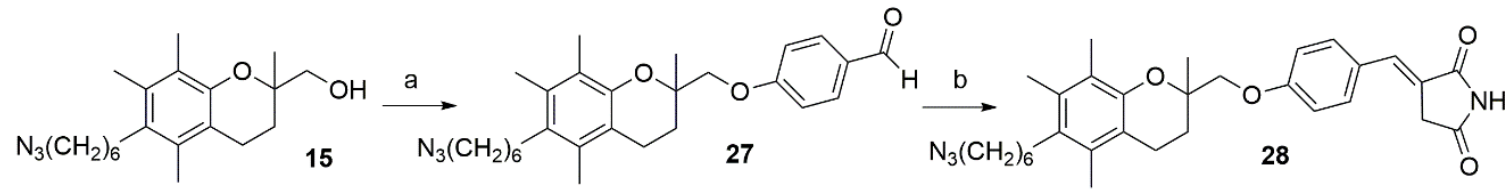

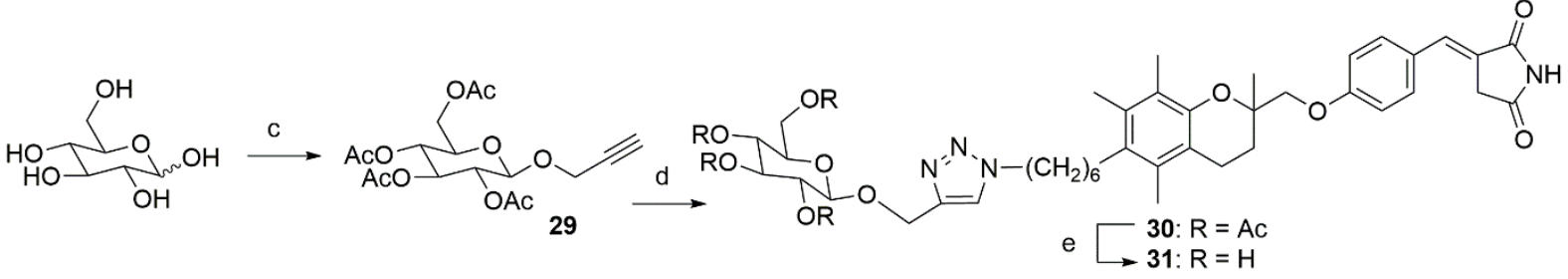


Scheme 6. Reagents and conditions: (a) $\mathrm{Tf}_{2} \mathrm{O}, \mathrm{Pyr}$., $\mathrm{CH}_{2} \mathrm{Cl}_{2}$, then 4-hydroxybenzaldehyde, $\mathrm{Cs}_{2} \mathrm{CO}_{3}$, DMF; (b) 2 , $\mathrm{MeOH}, \mathrm{RT}$; (c) $\mathrm{Ac}_{2} \mathrm{O}$, AcONa, then propargyl alcool, $\mathrm{BF}_{3} . \mathrm{OEt}_{2}, \mathrm{CH}_{2} \mathrm{Cl}_{2}$; (d) 28, $\mathrm{CuSO}_{4}$, sodium ascorbate, $t$ $\mathrm{BuOH} / \mathrm{MeOH}$; (e) $\mathrm{MeONa}, \mathrm{MeOH}$.

\section{Biological studies and discussion}

The synthesized molecules were tested for their anti-proliferative activity against 4 breast cancer cell lines: one hormone-dependent (MCF-7) and 3 TNBC derived (hormoneindependent) (MDA-MB-231, MDA-MB-435, and Hs578T) breast cancer cell lines. The results are expressed as $\mathrm{IC}_{50}$ in the Table 1 . TGZ and $\Delta 2$-TGZ, prepared as previously reported [12], were also tested for comparison. The representative dose-dependent responses of MDA-MB-231 cancer cells to TGZ and compound $\mathbf{1 0}$ are presented in supplementary data.

Table 1. Anti-proliferative activity of TGZ and some derivatives on different breast cancer cell lines.

\begin{tabular}{|c|c|c|c|c|}
\hline \multirow{2}{*}{ Compound } & \multicolumn{4}{|c|}{$\mathrm{IC}_{50}{ }^{\mathrm{a}}$} \\
\hline & $\mathrm{MCF}-7^{\mathrm{b}}$ & MDA-MB-231 & MDA-MB- $453^{\mathrm{c}}$ & $\mathrm{Hs}^{2} 78 \mathrm{~T}^{\mathrm{c}}$ \\
\hline TGZ & $74.3 \pm 3.9$ & $45.5 \pm 3.7$ & $67.1 \pm 6.1$ & $>100$ \\
\hline $6(\mathrm{TSN})$ & $35.9 \pm 3.1$ & $61.2 \pm 2.9$ & $35.8 \pm 4.1$ & $72.6 \pm 6.8$ \\
\hline 5 & $15.8 \pm 3.9$ & $28.0 \pm 2.0$ & $13.6 \pm 2.0$ & $38.2 \pm 3.4$ \\
\hline$\Delta 2$-TGZ & $57.0 \pm 4.4$ & $56.5 \pm 3.3$ & $58.3 \pm 4.1$ & $>100$ \\
\hline 4 & $13.2 \pm 1.3$ & $32.4 \pm 3.3$ & $13.2 \pm 1.0$ & $38.9 \pm 2.2$ \\
\hline 3 & $6.7 \pm 0.6$ & $20.6 \pm 1.0$ & $3.9 \pm 0.4$ & $30.8 \pm 1.3$ \\
\hline 9 & $4.0 \pm 0.2$ & $5.4 \pm 0.7$ & $1.04 \pm 0.2$ & $6.4 \pm 0.8$ \\
\hline 10 & $5.8 \pm 0.4$ & $5.9 \pm 0.1$ & $3.5 \pm 0.1$ & $8.8 \pm 0.6$ \\
\hline \multicolumn{5}{|c|}{$\begin{array}{l}\text { Concentration }(\mu \mathrm{M}) \text { required to decrease tumor cell number by } 50 \% \pm \text { SEM (Standard Error of the Mean). } \\
\text { b } \\
\text { Hormone-dependent breast cancer cell line. } \\
\text { Formone-independent breast cancer cell line. } \\
\text { First of all, we could notice that the highest } \mathrm{IC}_{50} \text { values (corresponding to the lowest } \\
\text { activities) were obtained with the Hs578T cell line, while the most sensitive cell line (except } \\
\text { for TGZ) was MDA-MB-453. Hs578T cells were not sensitive to TGZ and } \Delta 2-\mathrm{TGZ} \text {, but the } \\
\mathrm{IC}_{50} \text { of all the other molecules were lower than } 100 \mu \mathrm{M} \text {, whatever the cell line. Removal of } \\
\text { the sulfur atom of TGZ yielded } 6 \text { and our tests confirmed that this molecule (named TSN in } \\
\text { other studies) was more active than TGZ, except against the MDA-MB-231 cell line. The } \\
\text { lipophilic Boc-derived compound } 5 \text { was approximately two-fold more active than } 6 \text {, in } \\
\text { accordance with our previous results in the sulfured series [12]. } \Delta 2-\mathrm{TGZ} \text { showed a slightly } \\
\text { better potency than TGZ as expected, and the removal of the sulfur afforded } 4 \text { (which we } \\
\text { could name } \Delta 2-\mathrm{TSN} \text { ), which was more potent than both } \Delta 2-\mathrm{TGZ} \text { and the related saturated }\end{array}$} \\
\hline
\end{tabular}


compound 6. Thus, the presence of the double bond shows a synergistic effect with the removal of the sulfur atom. It is interesting to notice that the introduction of the double bond on 6 to give compound 4 , has the same enhancing effect on the activity than the adjunction of the Boc group on 6, as $\mathbf{4}$ and $\mathbf{5}$ have c.a. the same anti-proliferative activity toward each cell line. Furthermore, the adjunction of the Boc group on $\mathbf{4}$ afforded very active compound $\mathbf{3}$, with low micromolar activity on two cell lines. Finally, the addition of a $N$-Boc protected aminoalkyl chain gave compound $\mathbf{9}$, which showed a further fourfold increase in potency compared to $\mathbf{3}$ for the three hormone-independent breast cancer cell lines, and a lower effect against MCF-7. Removal of the Boc protecting group yielded $\mathbf{1 0}$ which showed a slightly lower activity than 9. Altogether, one can notice that the removal of the sulfur atom has a synergistic effect with the chemical modifications which were previously showed to increase the potency, i.e. the presence of a double bond and of a lipophilic group at the 6-position of the chromane heterocycle. This approach led to very active compounds $\mathbf{9}$ and $\mathbf{1 0}$ with lowmicromolar activities. Because of its lower lipophilicity, we chose compound $\mathbf{1 0}$ for further consideration. We then studied the effect of compound $\mathbf{1 0}$ on two other cancer cell lines: HCT116 (colon cancer) and U87 (glioblastoma). This molecule displayed an anticancer effect with $\mathrm{IC}_{50}$ values of $6.4 \pm 0.4 \mu \mathrm{M}$ and $8.7 \pm 1.1 \mu \mathrm{M}$ on these two cell lines respectively. These values were in a similar range than those measured in breast cancer cells. The sensibility of U87 cell to compound $\mathbf{1 0}$ is to be emphasized when considering the actual difficulty to treat the very aggressive glioblastoma tumors[25]. In contrast, exposure of non tumoral primary hepatocytes to compound $\mathbf{1 0}$ afforded a much higher $\mathrm{IC}_{50}$ of $42.1 \mu \mathrm{M}$, showing an interesting selectivity.

Besides, we intended to separate both enantiomers of compound $\mathbf{1 0}$ by using a kinetic resolution method. It allowed us to evaluate the anti-proliferative activity of each isomer. We tested them against two representative breast cancer cell lines: a hormone-dependent one (MCF-7) and a triple negative (hormone-independent) one (MDA-MB-231). The measured $\mathrm{IC}_{50}$ were unexpected (Table 2). Concerning MCF-7, both $(R)(10.9 \mu \mathrm{M})$ and $(S)(9.9 \mu \mathrm{M})$ isomers were significantly less active than the racemic compound $(5.8 \mu \mathrm{M})$. On the other hand, the opposite was seen concerning the MDA-MB-231 cell line: both isomers were more active than the racemic compound $(5.9 \mu \mathrm{M}),(S)$ derivative being the most potent one with $\mathrm{IC}_{50}=2.7 \mu \mathrm{M}$. It is quite difficult to rationalize, since we expected to have the antiproliferative activity of the racemic compound as being roughly the mean of the $\mathrm{IC}_{50}$ of the two enantiomers in both cell lines. Without knowledge about the exact target of this family of compounds, one may however estimate that concerning the hormone-dependent cell line, both enantiomers have a synergistic action whereas in the hormone-independent one, when they are mixed in the racemic mixture, they somehow impede each other.

Furthermore, we envisioned to vectorize our lead compound in order to preferentially target cancer cells. Due to the famous Warburg effect [26,27], the rate of the aerobic glycolysis is higher in cancerous cells than in normal cells, leading to an overexpression of the glucose receptors. Thus, we chose a strategy consisting in the addition of a glucose unit to our compound. Numerous examples of this strategy have been reported [28]. As depicted above, azide analog 28 was easily prepared, which was linked to an alkyne-derived peracetylated glucose via a copper-mediated cycloaddition, giving 30. Final deacetylation gave target compound 31. As depicted in Table 2, the azide intermediate $\mathbf{2 8} \mathrm{kept}$ a fair anti-proliferative activity, but lower than compound 10. Grafting the peracetylated glucose unit (giving 30) totally abrogated the anti-proliferative activity toward MDA-MB-231 hormone-independent 
breast cancer cell line, but some activity was kept toward MCF-7 cell line, at the same level as TSN (6). Finally, the deprotected target compound $\mathbf{3 1}$ showed no activity against both cancer cell lines (Table 2). It seems clear that the nature of the substituents located at the end of the alkyl chain have a strong influence on the anti-proliferative activity. Replacing the primary amine of $\mathbf{1 0}$ by an azide group has a negative effect on the activity which could be attributed to the loss of H-bond donor. Unfortunately, the grafting of a glucose moiety is even more detrimental to the activity, in opposition to what was initially planned. In particular, the total absence of activity of compound $\mathbf{3 1}$ could find two explanations. First, one could consider that the high polarity of $\mathbf{3 1}$ prevents its passive diffusion into the cancerous cells, contrary to the other compounds. From another point of view, the glucose moiety of $\mathbf{3 1}$ could lead to a strong anchorage of the molecule on the cell surface via linkage to the glucose receptor, once again preventing any passive diffusion. This time, the loss of activity could be attributed to an unexpected inability of the whole molecular structure to enter the cell through the glucose receptor after anchoring to it.

Table 2. Anti-proliferative activity of TGZ derivatives on different breast cancer cell lines.

\begin{tabular}{lll}
\hline \multirow{2}{*}{ Compound } & \multicolumn{2}{c}{$\mathrm{IC}_{50}{ }^{\mathrm{a}}$} \\
\cline { 2 - 3 } & $\mathrm{MCF-7}{ }^{\mathrm{b}}$ & \multicolumn{1}{c}{$\mathrm{MDA}-\mathrm{MB}-231^{\mathrm{c}}$} \\
\hline rac-10 & $5.8 \pm 0.4$ & $5.9 \pm 0.1$ \\
$(\boldsymbol{R}) \mathbf{- 1 0}$ & $10.9 \pm 1.7$ & $4.3 \pm 0.3$ \\
$(\boldsymbol{S}) \mathbf{- 1 0}$ & $9.9 \pm 0.9$ & $2.7 \pm 0.4$ \\
$\mathbf{2 8}$ & $18.1 \pm 1.7$ & $21.7 \pm 3.4$ \\
$\mathbf{3 0}$ & $33.4 \pm 7.9$ & $>100$ \\
$\mathbf{3 1}$ & $>100$ & $>100$ \\
\hline
\end{tabular}

The activity of compound $\mathbf{1 0}$ was further characterized in the triple-negative breast cancer cell line MDA-MB-231. Cell cycle analysis performed by flow cytometry revealed that $23.4 \pm$ $5.8 \%$ and $43.9 \pm 7 \%$ of compound 10-treated cells were detected in the sub-G1 fraction, corresponding to the apoptotic cells, after 48 and $72 \mathrm{~h}$, respectively (figure 4A). By contrast, in cells exposed to TGZ, there was no significant increase in the number of cells in the subG1 fraction compared to control cells (DMSO) (figure 4B). These data are in accordance with our previous results [29] showing that the related compound $\Delta 2-\mathrm{TGZ}$ induced only a slight increase $(<5 \%)$ in the proportion of MDA-MB-231 cells number in the sub- $\mathrm{G}_{1}$ fraction. After $48 \mathrm{~h}$ of TGZ treatment, in comparison to control cells, we observed an increase in the proportion of cells in the $\mathrm{G}_{0} / \mathrm{G}_{1}$ phase $(85.5 \pm 0.3 \%$ versus $62.6 \pm 0.5 \%)$ and a decrease in the proportion of cells in the $\mathrm{S}$ phase $(2.3 \pm 0.2 \%$ versus $15.7 \pm 0.4 \%)$ and $\mathrm{G} 2 / \mathrm{M}$ phase $(10.4 \pm$ $0.6 \%$ versus $20.5 \pm 0.6 \%$ ). The situation was similar after $72 \mathrm{~h}: 80 \pm 3.8 \%$ versus $62 \pm 2.7 \%$ 
in $\mathrm{G}_{0} / \mathrm{G}_{1}$ phase; $1.9 \pm 0.1 \%$ versus $13.1 \pm 1.2 \%$ in $\mathrm{S}$ phase; $12.2 \pm 0.8 \%$ versus $19.5 \pm 0.5 \%$ in $\mathrm{G} 2 / \mathrm{M}$ phase. This indicates a cell cycle arrest in the $\mathrm{G}_{0} / \mathrm{G}_{1}$ phase induced by TGZ that we also previously reported in MDA-MB-231 cells after exposure to the related compound $\Delta 2$-TGZ [29]. In compound 10-treated cells, we observed a global decrease in the cell number in the three phases of the cell cycle after 48 and $72 \mathrm{~h}$ of treatment. After a $48 \mathrm{~h}$ treatment, this decrease was significant only for cells in the $S$ phase $(8 \pm 0.8 \%$ versus $14.8 \pm 0.2 \%)$. After 72 $h$ of treatment, the decrease was significant for cells in the $G_{0} / G_{1}$ phase $(35 \pm 3.9 \%$ versus $62.4 \pm 1 \%)$ and for cells in the $S$ phase $(6.1 \pm 0.9 \%$ versus $11.8 \pm 0.9 \%)$. Thus, in contrast to TGZ and $\Delta 2$-TGZ which are cytostatic agents inducing a cell cycle arrest in $\mathrm{G}_{0} / \mathrm{G}_{1}$ phase, compound $\mathbf{1 0}$ appears as a potent pro-apoptotic molecule.

A

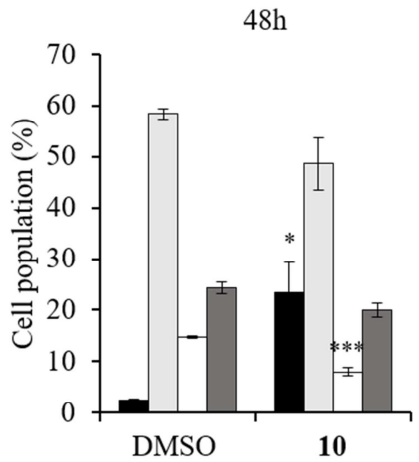

$\mathrm{B}$

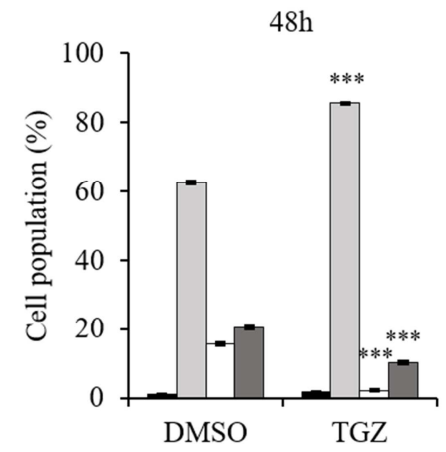

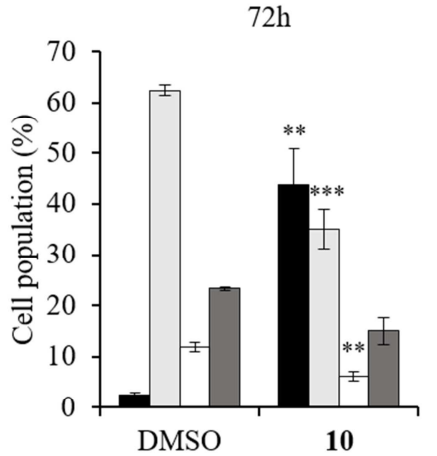

- Sub-G1 $\square \mathrm{G} 0 / \mathrm{G} 1$ $\square \mathrm{S}$ $\square \mathrm{G} 2 / \mathrm{M}$

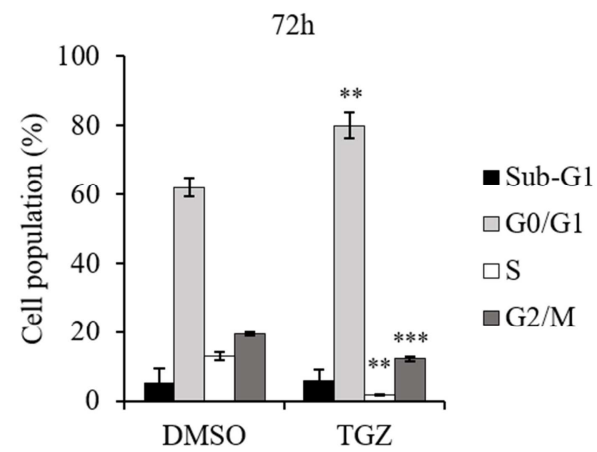

Fig. 4. Compound 10 increases the sub-G1 population of MDA-MB-231 breast cancer cells whereas TGZ induces cell cycle arrest. MDA-MB-231 cells were treated for indicated times with $6 \mu \mathrm{M}$ of $\mathbf{1 0}$ (A), $45 \mu \mathrm{M}$ of TGZ (B) or DMSO for control cells. Cell cycle was analyzed by flow cytometry. Bar diagrams represent the percentage of cells in the different phases of the cell cycle. Data are represented as mean \pm standard error of the mean of at least three independent experiments. Statistical significances of treated cells compared to control cells are indicated $(*, \mathrm{p}<0.05 ; * *, \mathrm{p}<0.01 ; * * *, \mathrm{p}<0.001)$.

To confirm the pro-apoptotic activity of compound 10, caspase $3 / 7$ activity was measured after 48 and 72 hours of treatment (figure 5A). Compound 10 induced a 2.7-fold and 1.4-fold increase of MDA-MB-231 caspase 3/7 activity after $48 \mathrm{~h}$ and $72 \mathrm{~h}$ treatment respectively, compared to control cells. The lower, but significant, increase in caspase $3 / 7$ activity after 72 hours of treatment could be explained by the 1.7-fold increase in the basal level of caspase 3/7 activity in control cells between $48 \mathrm{~h}$ and $72 \mathrm{~h}$ conditions. To comfort these data, we further determined the percentage of apoptotic cells by propidium iodide (nuclear labelling of dead cells) and FITC-Annexin V double-staining followed by flow cytometry analysis (figure 5B and 5C). Annexin $\mathrm{V}$ is an apoptosis marker able to bind to phosphatidyl serine, a membrane component translocated from the cytoplasmic face of the plasma membrane to the 
cell surface during apoptosis. Compound 10 induced a 2.3-fold and 3.7-fold (23.8 $\pm 4.3 \%$ versus $10.4 \pm 1.3 \%$ and $37.4 \pm 4.3 \%$ versus $10.2 \pm 0.9 \%$ ) significant increase of the proportion of MDA-MB-231 labelled with FITC-Annexin V after $48 \mathrm{~h}$ and $72 \mathrm{~h}$ treatment respectively, compared to control cells (figure 5B and 5C). Overall, these convergent results show that compound $\mathbf{1 0}$ is not a cytostatic but a pro-apoptotic agent in the TNBC cell line MDA-MB-231.

A

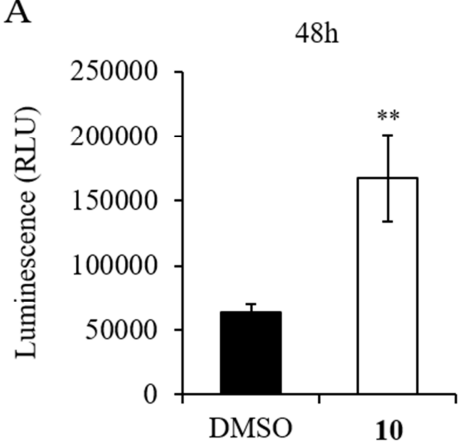

B

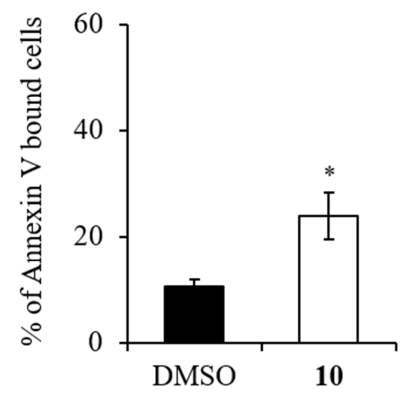

$\mathrm{C}$

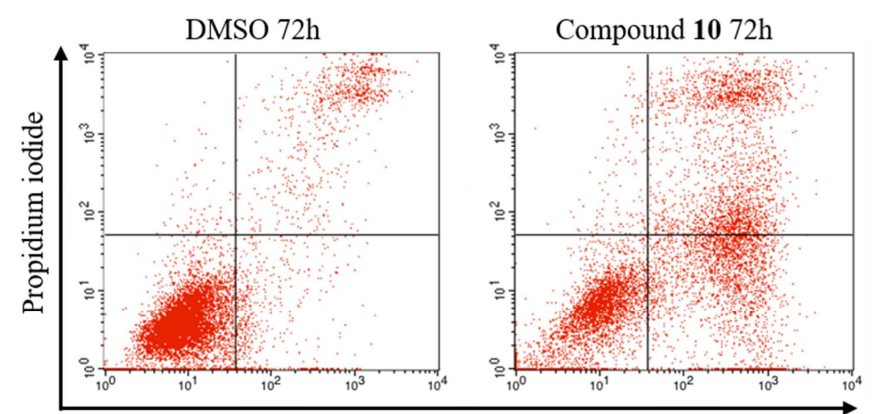

FITC-Annexin V

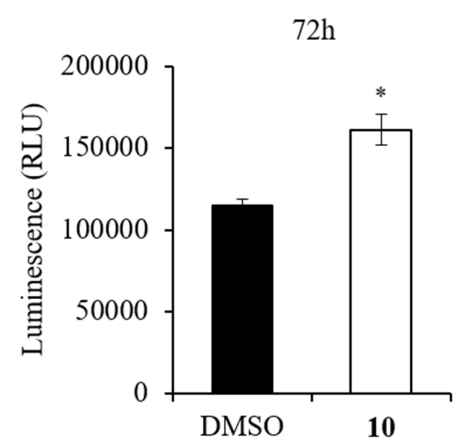

$72 \mathrm{~h}$

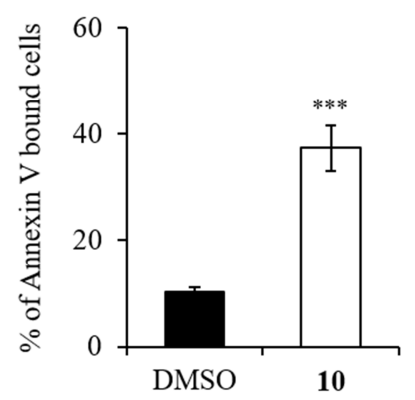

Fig. 5. Compound 10 induces apoptosis of MDA-MB-231 breast cancer cells. MDA-MB-231 cells were treated for indicated times with $6 \mu \mathrm{M}$ of $\mathbf{1 0}$ or DMSO for control cells. (A) Caspase 3/7 activity was measured by a luminescent method. (B) Double-staining intensity with Propidium Iodide and Annexin V was quantified by flow cytometry and bar graphs show the percentage of apoptotic cells. (C) Dot-plot graphs representative of the flow cytometry analysis: the annexin $\mathrm{V}$ labeled apoptotic cells are localized in the lower and upper right quadrants. Data are represented as mean \pm standard error of the mean of at least three independent experiments. Statistical significances of treated cells compared to control cells are indicated $(*, p<0.05 ; * *, p<0.01 ; * * *$, $\mathrm{p}<0.001)$.

\section{Conclusion}


In this study, numerous desulfured derivatives of TGZ were prepared and tested for their antiproliferative activity against hormone-dependent and hormone-independent breast cancer cell lines. A clear synergistic effect on the activity was observed between the desulfuration and our previously reported key structural modifications of the TGZ template. This led to very active compounds from which the best ones exhibited low-micromolar activities. Synthetic efforts were done in order to scale up initial procedures at the multi-gram scale and a kinetic resolution method was used to prepare and evaluate both isomers of the most promising compound (10). Flow cytometry, caspase 3/7 activity measurement and FITC-Annexin V double staining showed that this compound is clearly a pro-apoptotic agent. Further studies are ongoing in our team to better understand the underlying mode of action of this compound.

\section{Experimental protocols}

\subsection{Chemistry}

\subsubsection{General methods}

Diethylether and toluene were dried using a MBRAUN MB-SPS-800 solvent purification system. Other solvents and liquid reagents were purified and dried according to recommended procedures. Chemical reagents were purchased from Merck, Fisher Scientific or TCI Europe and were used as received. Amano lipase PS from Burkholderia cepacia and Hyflo Supercel ${ }^{\circledR}$ were purchased from Sigma-Aldrich. Analytical thin-layer chromatography was performed with silica gel 60 F254, $0.25 \mathrm{~mm}$ pre-coated TLC plates (Merck). Compounds were visualized using UV light ( $254 \mathrm{~nm}$ ) and a solution of cerium sulfate tetrahydrate and phosphomolybdic acid in $10 \%$ aqueous sulfuric acid as developing agent. Alternatively, a 1\% ethanolic solution of ninhydrin or a potassium permanganate aqueous solution were used. Column chromatographies were performed using a Grace Reveleris ${ }^{\circledR}$ apparatus using $40 \mu \mathrm{M}$ silica gel. NMR spectra were recorded at 303K on a Bruker Avance III $200\left(200 \mathrm{MHz}\right.$ for ${ }^{1} \mathrm{H}$ and 50.3 $\mathrm{MHz}$ for $\left.{ }^{13} \mathrm{C}\right)$, DPX250 $\left(250 \mathrm{MHz}\right.$ for ${ }^{1} \mathrm{H}$ and $62.9 \mathrm{MHz}$ for $\left.{ }^{13} \mathrm{C}\right)$ or on a Bruker DRX400 (400 MHz for ${ }^{1} \mathrm{H}$ and $100.6 \mathrm{MHz}$ for ${ }^{13} \mathrm{C}$ ) spectrometer. The chemical shifts are reported in ppm $(\delta)$ relative to residual solvent peak [30]. Mass spectra (MS) were recorded on a micrOTOFq (Bruker) ESI/QqTOF spectrometer. Melting points (M.p.) were determined with a Kofler bench and are uncorrected. FTIR spectra were recorded on a Perkin-Elmer spectrum 1000 spectrophotometer using a thin film deposition on $\mathrm{NaCl}$ window or $\mathrm{KBr}$ pellets, or on a Shimadzu IRAffinity-1 apparatus equipped with an ATR PIKE diamond gladiATR. Optical rotations were measured on an Anton Paar MCP 300 polarimeter (sodium D-line: $589 \mathrm{~nm}$ ) using a $10 \mathrm{~cm}$ cell at $20{ }^{\circ} \mathrm{C}$ in $\mathrm{CHCl}_{3}$ or $10 \% \mathrm{v} / \mathrm{v} \mathrm{MeOH}$ in $\mathrm{CHCl}_{3}$, and the concentration is expressed in $\mathrm{g} / 100 \mathrm{~mL}$. Elemental analyses were performed using a Thermofinnigan Flash EA 1112 apparatus.

5.1.2. (E)-tert-butyl (2-((4-((2,5-dioxopyrrolidin-3-ylidene)methyl)phenoxy)methyl)-2,5,7,8tetramethylchroman-6-yl) carbonate (3) 
To a solution of compound $1(2.30 \mathrm{~g}, 5.22 \mathrm{mmol})$ in dry $\mathrm{MeOH}(160 \mathrm{~mL})$ was added the phosphoranylidene 2 (1.88 g, $5.22 \mathrm{mmol}$ ). The suspension was stirred at room temperature under argon for $24 \mathrm{~h}$, filtered, and washed with cooled $\mathrm{MeOH}$. The crude compound was purified by column chromatography (eluent: cyclohexane/EtOAc, 80:20) to give $2.01 \mathrm{~g} \mathrm{(3.85}$ mmol, 74\% yield) of white crystals. M.p. $206-208^{\circ} \mathrm{C}$. IR (film) $v\left(\mathrm{~cm}^{-1}\right): 3163,2918,1745$, 1703, 1601, 1514, 1342, 1234, 1170, 1155, 1093, 839. ${ }^{1} \mathrm{H}$ NMR (400 MHz, $\left.\mathrm{CDCl}_{3}\right): \delta 1.42$ (s, $\left.3 \mathrm{H}, \mathrm{CH}_{3}\right), 1.55(\mathrm{~s}, 9 \mathrm{H}, t-\mathrm{Bu}), 1.89\left(\mathrm{~m}, 1 \mathrm{H}\right.$, chromane 3-HaHb), $2.04\left(\mathrm{~s}, 3 \mathrm{H}, \mathrm{CH}_{3}\right), 2.06(\mathrm{~s}$, $\left.3 \mathrm{H}, \mathrm{CH}_{3}\right), 2.08\left(\mathrm{~s}, 3 \mathrm{H}, \mathrm{CH}_{3}\right), 2.13(\mathrm{~m}, 1 \mathrm{H}$, chromane 3-HaHb), $2.64(\mathrm{~m}, 2 \mathrm{H}$, chromane 4$\mathrm{CH}_{2}$ ), 3.57 (d, $J=1.9 \mathrm{~Hz}, 2 \mathrm{H}, \mathrm{CH}_{2} \mathrm{CO}$ ), 3.94, 4.04 (AB system, $\left.J=9.5 \mathrm{~Hz}, 2 \mathrm{H}, \mathrm{OCH}_{2}\right), 6.99$ (d, $\left.J=8.7 \mathrm{~Hz}, 2 \mathrm{H}, \mathrm{H}_{\text {arom }}\right), 7.42\left(\mathrm{~d}, J=8.7 \mathrm{~Hz}, 2 \mathrm{H}, \mathrm{H}_{\text {arom }}\right), 7.55$ (br t, $\left.1 \mathrm{H}, \mathrm{CH}=\mathrm{C}\right), 8.40$ (br s, $1 \mathrm{H}, \mathrm{NH}) .{ }^{13} \mathrm{C} \mathrm{NMR}\left(100 \mathrm{MHz}, \mathrm{CDCl}_{3}\right): \delta 11.9\left(\mathrm{CH}_{3}\right), 12.0\left(\mathrm{CH}_{3}\right), 12.8\left(\mathrm{CH}_{3}\right), 20.2\left(\mathrm{CH}_{2}\right)$, $22.9\left(\mathrm{CH}_{3}\right), 27.8(t-\mathrm{Bu}), 28.4\left(\mathrm{CH}_{2}\right), 35.2\left(\mathrm{CH}_{2}\right), 72.8,74.5,83.0,115.6\left(\mathrm{CH}_{\text {arom }}\right)$, 117.3, 121.6, 123.3, 125.6, 127.0, 127.6, $132.2\left(\mathrm{CH}_{\text {arom }}\right), 135.0(\mathrm{CH}=\mathrm{C}), 141.5,148.9,152.4,160.9$, $171.3(\mathrm{C}=\mathrm{O}), 174.2(\mathrm{C}=\mathrm{O})$. ESI-MS (pos. mode): $\mathrm{m} / \mathrm{z}=544.23\left([\mathrm{M}+\mathrm{Na}]^{+}\right)$. Anal. Calcd for $\mathrm{C}_{30} \mathrm{H}_{35} \mathrm{NO}_{7},{ }_{1 / 3} \mathrm{H}_{2} \mathrm{O}$ (527.62): C, 68.29; H, 6.81; N, 2.65. Found: C, 68.35; H, 6.66; N, 2.64.

\subsection{3. (E)-3-(4-((6-hydroxy-2,5,7,8-tetramethylchroman-2-yl)methoxy)benzylidene)} pyrrolidine-2,5-dione (4)

To a solution of compound 3 (959 mg, $1.84 \mathrm{mmol}$ ) in $\mathrm{CH}_{2} \mathrm{Cl}_{2}(25 \mathrm{~mL})$ was added trifluoroacetic acid $(8 \mathrm{~mL})$. The mixture was stirred at room temperature for $1.5 \mathrm{~h}$ and the solvent was evaporated. The residue was dissolved in EtOAc $(70 \mathrm{~mL})$, the solution was washed with $5 \%$ aqueous $\mathrm{NaHCO}_{3}$ solution $(2 \times 50 \mathrm{~mL})$, water $(2 \times 50 \mathrm{~mL})$, dried $\left(\mathrm{MgSO}_{4}\right)$ and concentrated to dryness. The residue was crystallized in EtOH to give $565 \mathrm{mg}$ (1.28 mmol, $70 \%$ yield) of white crystals. M.p. $174-176^{\circ} \mathrm{C}$. IR (film) $v\left(\mathrm{~cm}^{-1}\right): 3415,2975,1749$, 1705, 1651, 1251. ${ }^{1} \mathrm{H}$ NMR $\left(400 \mathrm{MHz}, \mathrm{CDCl}_{3}\right): \delta 1.42\left(\mathrm{~s}, 3 \mathrm{H}, \mathrm{CH}_{3}\right), 1.92(\mathrm{~m}, 1 \mathrm{H}$, chromane 3- $\mathrm{HaHb}), 2.09\left(\mathrm{~s}, 3 \mathrm{H}, \mathrm{CH}_{3}\right), 2.10\left(\mathrm{~m}, 1 \mathrm{H}\right.$, chromane 3-HaHb), $2.12\left(\mathrm{~s}, 3 \mathrm{H}, \mathrm{CH}_{3}\right), 2.16(\mathrm{~s}, 3 \mathrm{H}$, $\left.\mathrm{CH}_{3}\right), 2.66\left(\mathrm{~m}, 2 \mathrm{H}\right.$, chromane 4- $\left.\mathrm{CH}_{2}\right), 3.58\left(\mathrm{~d}, J=2.2 \mathrm{~Hz}, 2 \mathrm{H}, \mathrm{CH}_{2} \mathrm{CO}\right), 3.95,4.04(\mathrm{AB}$ system, $\left.J=9.2 \mathrm{~Hz}, 2 \mathrm{H}, \mathrm{OCH}_{2}\right), 4.27(\mathrm{~s}, 1 \mathrm{H}, \mathrm{OH}), 7.00\left(\mathrm{~d}, J=8.8 \mathrm{~Hz}, 2 \mathrm{H}, \mathrm{H}_{\text {arom }}\right), 7.42(\mathrm{~d}, J=$ $\left.8.8 \mathrm{~Hz}, 2 \mathrm{H}, \mathrm{H}_{\text {arom }}\right), 7.55$ (br t, $\left.1 \mathrm{H}, \mathrm{CH}=\mathrm{C}\right), 8.11$ (br s, $\left.1 \mathrm{H}, \mathrm{NH}\right) .{ }^{13} \mathrm{C} \mathrm{NMR}\left(100 \mathrm{MHz}, \mathrm{CDCl}_{3}\right)$ :

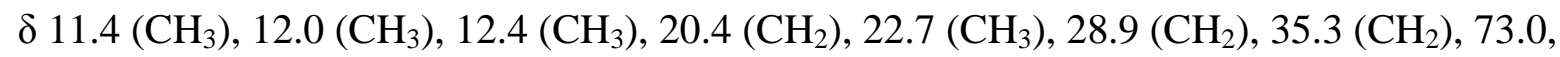
74.1, $115.6\left(\mathrm{CH}_{\text {arom }}\right), 117.3,118.7,121.4,121.5,122.9,126.9,132.2\left(\mathrm{CH}_{\text {arom }}\right), 135.1(\mathrm{CH}=\mathrm{C})$, 145.1, 145.2, 161.0, $171.1(\mathrm{C}=\mathrm{O}), 174.0(\mathrm{C}=\mathrm{O})$. ESI-MS (pos. mode): $\mathrm{m} / \mathrm{z}=460.15$ $\left([\mathrm{M}+\mathrm{K}]^{+}\right)$. Anal. Calcd for $\mathrm{C}_{25} \mathrm{H}_{27} \mathrm{NO}_{5}, \mathrm{H}_{2} \mathrm{O}$ (439.51): C, 68.32; H, 6.65; N, 3.19. Found: $\mathrm{C}$, $68.61 ; \mathrm{H}, 6.28 ; \mathrm{N}, 3.30$.

\subsection{4 tert-butyl (2-((4-((2,5-dioxopyrrolidin-3-yl)methyl)phenoxy)methyl)-2,5,7,8-} tetramethylchroman-6-yl) carbonate (5)

In a round bottom flask was first introduced $10 \%$ palladium on carbon $(10 \mathrm{mg})$, in order to avoid any ignition of the solvent. A solution of $\mathbf{3}(100 \mathrm{mg}, 0.19 \mathrm{mmol})$ in EtOAc $(10 \mathrm{~mL})$ was then added. The mixture was stirred under hydrogen atmosphere for $18 \mathrm{~h}$ at room temperature, then filtered on celite ${ }^{\circledR}$ and the solvent was removed under reduced pressure. The residue was purified by column chromatography (eluent: cyclohexane/EtOAc, 100:0 to 70:30) to afford 5 as a colorless foam (45 mg, $0.09 \mathrm{mmol}, 47 \%$ yield). M.p. $69-71{ }^{\circ} \mathrm{C}$. IR (ATR): $v$ $\left(\mathrm{cm}^{-1}\right) 3169,2928,1749,1714,1609,1510,1456,1367 .{ }^{1} \mathrm{H}$ NMR $\left(400 \mathrm{MHz}, \mathrm{CDCl}_{3}\right): \delta 1.41$ $\left(\mathrm{s}, 3 \mathrm{H}, \mathrm{CH}_{3}\right), 1.55(\mathrm{~s}, 9 \mathrm{H}, t-\mathrm{Bu}), 1.88\left(\mathrm{~m}, 1 \mathrm{H}\right.$, chromane $\left.3-H_{a} \mathrm{H}_{\mathrm{b}}\right), 2.03\left(\mathrm{~s}, 3 \mathrm{H}, \mathrm{CH}_{3}\right), 2.08(\mathrm{~s}$, $\left.6 \mathrm{H}, 2 \times \mathrm{CH}_{3}\right), 2.13\left(\mathrm{~m}, 1 \mathrm{H}\right.$, chromane $\left.3-\mathrm{H}_{\mathrm{a}} H_{b}\right), 2.49$ (A part of an ABX system, $J=18.4,5.0$ $\left.\mathrm{Hz}, 1 \mathrm{H}, \mathrm{PhCH}_{a} \mathrm{H}_{\mathrm{b}}\right), 2.63\left(\mathrm{~m}, 2 \mathrm{H}\right.$, chromane 4- $\mathrm{CH}_{2}$ ), 2.72 (B part of an ABX system, $J=18.4$, 
$\left.9.0 \mathrm{~Hz}, 1 \mathrm{H}, \mathrm{PhCH}_{\mathrm{a}} H_{b}\right), 2.87\left(\mathrm{~m}, 1 \mathrm{H}, \mathrm{TZD} \mathrm{CHCH} \mathrm{H}_{\mathrm{b}}\right), 3.09-3.19\left(\mathrm{~m}, 2 \mathrm{H}, \mathrm{TZD} \mathrm{CHCH}{ }_{\mathrm{a}} H_{b}+\right.$ $\mathrm{CHCH}_{\mathrm{a}} \mathrm{H}_{\mathrm{b}}$ ), 3.84, 3.96 (AB system, $\left.J=9.1 \mathrm{~Hz}, \mathrm{OCH}_{2}\right), 6.85\left(\mathrm{~d}, J=8.7 \mathrm{~Hz}, 2 \mathrm{H}, \mathrm{H}_{\text {arom }}\right), 7.07$ $\left(\mathrm{d}, J=8.7 \mathrm{~Hz}, 2 \mathrm{H}, \mathrm{H}_{\text {arom }}\right), 7.95($ br s, $1 \mathrm{H}, \mathrm{NH}) .{ }^{13} \mathrm{C} \mathrm{NMR}\left(100 \mathrm{MHz}, \mathrm{CDCl}_{3}\right): \delta 11.9\left(\mathrm{CH}_{3}\right)$, $12.0\left(\mathrm{CH}_{3}\right), 12.8\left(\mathrm{CH}_{3}\right), 20.3\left(\mathrm{CH}_{2}\right), 23.1\left(\mathrm{CH}_{3}\right), 27.8(t-\mathrm{Bu}), 28.4\left(\mathrm{CH}_{2}\right), 34.4\left(\mathrm{CH}_{2}\right), 35.5$ $\left(\mathrm{CH}_{2}\right), 43.0(\mathrm{CH}), 72.7,74.7,82.9,115.2\left(\mathrm{CH}_{\text {arom }}\right), 117.4,123.2,125.1,127.4,129.2,130.2$ $\left(\mathrm{CH}_{\text {arom }}\right), 141.4,149.0,152.4,158.3,176.2(\mathrm{C}=\mathrm{O}), 179.3(\mathrm{C}=\mathrm{O})$. ESI-MS (pos. mode): $\mathrm{m} / \mathrm{z}=$ $446.25[\mathrm{M}+\mathrm{Na}]^{+}$. Anal. Calcd for $\mathrm{C}_{25} \mathrm{H}_{29} \mathrm{NO}_{5}, 1 / 2 \mathrm{H}_{2} \mathrm{O}$ (432.52): C, 69.43; H, 6.99; N, 3.24.

Found: C, 69.20; H, 7.06; N, 3.05.

\subsubsection{3-(4-((6-hydroxy-2,5,7,8-tetramethylchroman-2-yl)methoxy)benzyl)pyrrolidine-2,5- dione (6)}

In a round bottom flask was first introduced $10 \%$ palladium on carbon $(10 \mathrm{mg})$, in order to avoid any ignition of the solvent. A suspension of 4 (100 mg, $0.24 \mathrm{mmol})$ in EtOAc $(10 \mathrm{~mL})$ was then added. The mixture was stirred under hydrogen atmosphere for $18 \mathrm{~h}$ at room temperature, then filtered on celite ${ }^{\circledR}$ and the solvent was removed under reduced pressure to give a pale yellow foam (91 mg, $0.21 \mathrm{mmol}, 89 \%$ yield). M.p. $75-77^{\circ} \mathrm{C}$. IR (ATR): $v\left(\mathrm{~cm}^{-1}\right)$ 3486, 3200, 2922, 1771, 1699, 1608, 1510, 1456, 1418, 1352. ${ }^{1} \mathrm{H}$ NMR $\left(400 \mathrm{MHz}, \mathrm{CDCl}_{3}\right): \delta$ $1.41\left(\mathrm{~s}, 3 \mathrm{H}, \mathrm{CH}_{3}\right), 1.89\left(\mathrm{~m}, 1 \mathrm{H}\right.$, chromane-3- $\left.\mathrm{H}_{a} \mathrm{H}_{\mathrm{b}}\right), 2.10\left(\mathrm{~s}, 3 \mathrm{H}, \mathrm{CH}_{3}\right), 2.11\left(\mathrm{~s}, 3 \mathrm{H}, \mathrm{CH}_{3}\right), 2.12$ $\left(\mathrm{m}, 1 \mathrm{H}\right.$, chromane-3- $\left.\mathrm{H}_{\mathrm{a}} H_{b}\right), 2.16\left(\mathrm{~s}, 3 \mathrm{H}, \mathrm{CH}_{3}\right), 2.48$ (A part of an ABX system, $J=18.5,4.9$ $\left.\mathrm{Hz}, 1 \mathrm{H}, \mathrm{PhCH}_{a} \mathrm{H}_{\mathrm{b}}\right), 2.64(\mathrm{~m}, 2 \mathrm{H}$, chromane 4-CH$), 2.71$ (B part of an ABX system, $J=18.5$, $\left.9.0 \mathrm{~Hz}, 1 \mathrm{H}, \mathrm{PhCH}_{\mathrm{a}} H_{b}\right), 2.88\left(\mathrm{~m}, 1 \mathrm{H}, \mathrm{TZD} \mathrm{CHCH} \mathrm{H}_{\mathrm{b}}\right), 3.07-3.19\left(\mathrm{~m}, 2 \mathrm{H}, \mathrm{TZD} \mathrm{CHCH}{ }_{\mathrm{a}} H_{b}+\right.$ $\mathrm{CHCH}_{\mathrm{a}} \mathrm{H}_{\mathrm{b}}$ ), 3.86-3.96 (AB system, $J=9.1 \mathrm{~Hz}, \mathrm{CH}_{2} \mathrm{O}$ ), 4.33 (br s, $\left.1 \mathrm{H}, \mathrm{OH}\right), 6.86$ (d, $J=8.6$ $\left.\mathrm{Hz}, 2 \mathrm{H}, \mathrm{H}_{\text {arom }}\right), 7.07$ (d, $\left.J=8.6 \mathrm{~Hz}, 2 \mathrm{H}, \mathrm{H}_{\text {arom }}\right), 8.20$ (br s, $\left.1 \mathrm{H}, \mathrm{NH}\right) .{ }^{13} \mathrm{C} \mathrm{NMR}(100 \mathrm{MHz}$, $\left.\mathrm{CDCl}_{3}\right): \delta 11.4\left(\mathrm{CH}_{3}\right), 12.0\left(\mathrm{CH}_{3}\right), 12.3\left(\mathrm{CH}_{3}\right), 20.5\left(\mathrm{CH}_{2}\right), 22.9\left(\mathrm{CH}_{3}\right), 28.8\left(\mathrm{CH}_{2}\right), 34.4$ $\left(\mathrm{CH}_{2}\right), 35.4\left(\mathrm{CH}_{2}\right), 43.0(\mathrm{CH}), 72.8,74.2,115.2\left(\mathrm{CH}_{\text {arom }}\right), 117.5,118.7,121.4,122.8,129.1$, $130.1\left(\mathrm{CH}_{\text {arom }}\right), 145.1,145.2,158.4,176.5(\mathrm{C}=\mathrm{O}), 179.5(\mathrm{C}=\mathrm{O})$. ESI-MS (pos. mode): $\mathrm{m} / \mathrm{z}=$ $446.19[\mathrm{M}+\mathrm{Na}]^{+}$. Anal Calcd for $\mathrm{C}_{25} \mathrm{H}_{29} \mathrm{NO}_{5},{ }_{1 / 3} \mathrm{H}_{2} \mathrm{O}$ (429.52): C, 69.91; H, 6.96; N, 3.26. Found: C, 70.18; H, 7.02; N, 3.19.

\subsection{6 tert-butyl (6-(2-((4-formylphenoxy)methyl)-2,5,7,8-tetramethylchroman-6-yl)hexyl) carbamate ( 8 )}

Preparation of the triflate intermediate: to an ice cooled solution of anhydrous pyridine (445 $\mu \mathrm{L}, 5.5 \mathrm{mmol})$ in dry $\mathrm{CH}_{2} \mathrm{Cl}_{2}(5 \mathrm{~mL})$ was added dropwise trifluoromethanesulfonic anhydride $(211 \mu \mathrm{L}, 1.3 \mathrm{mmol})$ under argon. A solution of 7 (385 mg, $0.9 \mathrm{mmol})$ in $\mathrm{CH}_{2} \mathrm{Cl}_{2}(5 \mathrm{~mL})$ was added 5 minutes later to the reaction mixture. The solution was stirred for 20 minutes at $0{ }^{\circ} \mathrm{C}$ and the solvent was evaporated. The residue was dissolved in EtOAc $(15 \mathrm{~mL})$, the solution was washed with water $(2 \times 10 \mathrm{~mL}), 5 \%$ aqueous $\mathrm{NaHCO}_{3}$ solution $(2 \times 10 \mathrm{~mL})$, and brine $(2$ $\mathrm{x} 10 \mathrm{~mL})$. The organic phase was then dried $\left(\mathrm{MgSO}_{4}\right)$ and the solvent was removed under vacuum to afford a brownish liquid.

Condensation with 4-hydroxybenzaldehyde: to a solution of the above triflate in dry DMF (4 $\mathrm{mL}$ ) were added 4-hydroxybenzaldehyde (112 mg, $0.9 \mathrm{mmol}$ ) and $\mathrm{Cs}_{2} \mathrm{CO}_{3}$ (449 mg, 1.4 $\mathrm{mmol})$. The reaction mixture was stirred under argon at room temperature for $24 \mathrm{~h}$, and then EtOAc $(20 \mathrm{~mL})$ was added. The organic layer was washed with water $(2 \times 20 \mathrm{~mL}), 5 \%$ aqueous $\mathrm{NaHCO}_{3}$ solution $(2 \times 20 \mathrm{~mL})$, water $(2 \times 20 \mathrm{~mL})$, dried $\left(\mathrm{MgSO}_{4}\right)$ and the solvent 
was evaporated under vacuum to give a yellow liquid. The residue was purified by column chromatography (eluent: cyclohexane/EtOAc, 100:0 to 85:15) to afford $\mathbf{8}$ (328 $\mathrm{mg}, 0.63$ mmol, $68 \%$ yield) as a colorless liquid. ${ }^{1} \mathrm{H}$ NMR (400 MHz, $\left.\mathrm{CDCl}_{3}\right): \delta 1.43\left(\mathrm{~s}, 3 \mathrm{H}, \mathrm{CH}_{3}\right)$, 1.35-1.53 (m, 8H, linker $\left.\mathrm{CH}_{2}\right), 1.44(\mathrm{~s}, 9 \mathrm{H}, t-\mathrm{Bu}), 1.90\left(\mathrm{~m}, 1 \mathrm{H}\right.$, chromane $\left.3-H_{a} \mathrm{H}_{\mathrm{b}}\right), 2.10(\mathrm{~s}$, $\left.3 \mathrm{H}, \mathrm{CH}_{3}\right), 2.13\left(\mathrm{~m}, 1 \mathrm{H}\right.$, chromane $\left.3-\mathrm{H}_{\mathrm{a}} \mathrm{H}_{b}\right), 2.15\left(\mathrm{~s}, 3 \mathrm{H}, \mathrm{CH}_{3}\right), 2.20\left(\mathrm{~s}, 3 \mathrm{H}, \mathrm{CH}_{3}\right), 2.57-2.71$ (m, 4H, chromane 4- $\mathrm{CH}_{2}+$ linker $\mathrm{CH}_{2}$ ), 3.12 (m, 2H, $\mathrm{CH}_{2} \mathrm{NHBoc}$ ), 3.98, 4.08 (AB system, $J$ $=9.3 \mathrm{~Hz}, 2 \mathrm{H}, \mathrm{CH}_{2} \mathrm{O}$ ), 4.51 (br s, $\left.1 \mathrm{H}, \mathrm{NHBoc}\right), 7.03$ (d, $J=8.7 \mathrm{~Hz}, 2 \mathrm{H}, \mathrm{H}_{\text {arom }}$ ), 7.82 (d, $J=8.7$

$\left.\mathrm{Hz}, 2 \mathrm{H}, \mathrm{H}_{\text {arom }}\right), 9.88$ (s, $\left.1 \mathrm{H}, \mathrm{CHO}\right)$. Other analytical data were in accordance with the previous ones [13].

\subsection{7. tert-butyl (E)-(6-(2-((4-((2,5-dioxopyrrolidin-3-ylidene)methyl)phenoxy)methyl)- 2,5,7,8-tetramethylchroman-6-yl)hexyl)carbamate (9)}

To a solution of compound $\mathbf{8}(208 \mathrm{mg}, 0.40 \mathrm{mmol})$ in anhydrous $\mathrm{MeOH}(10 \mathrm{~mL})$ was added compound 2 (143 mg, $0.40 \mathrm{mmol}$ ). The suspension was stirred at room temperature under argon for $12 \mathrm{~h}$. The mixture was filtered and washed with cooled $\mathrm{MeOH}$ to give $153 \mathrm{mg}(0.25$ mmol, 63\% yield) of white powder. M.p. $205-207{ }^{\circ} \mathrm{C}$. IR (ATR) v $\left(\mathrm{cm}^{-1}\right): 3381,2924,1769$, $1705,1688,1603,1514,1308,1252,1163 .{ }^{1} \mathrm{H}$ NMR $\left(400 \mathrm{MHz}, \mathrm{CDCl}_{3}\right): \delta 1.43\left(\mathrm{~s}, 3 \mathrm{H}, \mathrm{CH}_{3}\right)$, $1.44\left(\mathrm{~m}, 8 \mathrm{H}\right.$, linker $\left.\mathrm{CH}_{2}\right), 1.45(\mathrm{~s}, 9 \mathrm{H}, t-\mathrm{Bu}), 1.90\left(\mathrm{~m}, 1 \mathrm{H}\right.$, chromane-3- $\left.H_{a} \mathrm{H}_{\mathrm{b}}\right), 2.10(\mathrm{~s}, 3 \mathrm{H}$, $\left.\mathrm{CH}_{3}\right), 2.12\left(\mathrm{~m}, 1 \mathrm{H}\right.$, chromane-3- $\left.\mathrm{H}_{\mathrm{a}} \mathrm{H}_{b}\right), 2.15\left(\mathrm{~s}, 3 \mathrm{H}, \mathrm{CH}_{3}\right), 2.20\left(\mathrm{~s}, 3 \mathrm{H}, \mathrm{CH}_{3}\right), 2.59(\mathrm{~m}, 2 \mathrm{H}$, linker $\left.\mathrm{CH}_{2}\right), 2.66\left(\mathrm{~m}, 2 \mathrm{H}\right.$, chromane 4- $\left.\mathrm{CH}_{2}\right), 3.12\left(\mathrm{~m}, 2 \mathrm{H}, \mathrm{CH}_{2} \mathrm{NHBoc}\right), 3.58(\mathrm{~d}, J=2.2 \mathrm{~Hz}$, $2 \mathrm{H}, \mathrm{CH}_{2} \mathrm{CO}$ ), 3.95, 4.05 (AB system, $J=9.2 \mathrm{~Hz}, 2 \mathrm{H}, \mathrm{OCH}_{2}$ ), 4.50 (br s, $1 \mathrm{H}, \mathrm{NHBoc}$ ), 7.00 $\left(\mathrm{d}, J=8.9 \mathrm{~Hz}, 2 \mathrm{H}, \mathrm{H}_{\text {arom }}\right), 7.42\left(\mathrm{~d}, J=8.9 \mathrm{~Hz}, 2 \mathrm{H}, \mathrm{H}_{\text {arom }}\right), 7.55$ (br t, $\left.J=2.2 \mathrm{~Hz}, 1 \mathrm{H}, \mathrm{CH}=\mathrm{C}\right)$, 8.09 (s, 1H, NH). ${ }^{13} \mathrm{C} \mathrm{NMR}\left(100 \mathrm{MHz}, \mathrm{CDCl}_{3}\right): \delta 12.2\left(\mathrm{CH}_{3}\right), 15.1\left(\mathrm{CH}_{3}\right), 16.0\left(\mathrm{CH}_{3}\right), 20.8$ $\left(\mathrm{CH}_{2}\right), 22.9\left(\mathrm{CH}_{3}\right), 26.8\left(\mathrm{CH}_{2}\right), 28.6(t-\mathrm{Bu}), 28.8\left(\mathrm{CH}_{2}\right), 30.0\left(\mathrm{CH}_{2}\right), 30.1\left(\mathrm{CH}_{2}\right), 30.2\left(\mathrm{CH}_{2}\right)$, $30.3\left(\mathrm{CH}_{2}\right), 35.3\left(\mathrm{CH}_{2}\right), 40.7\left(\mathrm{CH}_{2}\right), 73.0,74.2,115.6\left(\mathrm{CH}_{\text {arom }}\right), 116.9,121.4,122.3,126.8$, 131.1, 131.7, $132.2\left(\mathrm{CH}_{\text {arom }}\right), 133.6,135.1(\mathrm{CH}=\mathrm{C}), 149.1,156.1,161.0,171.0(\mathrm{C}=\mathrm{O}), 174.0$ $(\mathrm{C}=\mathrm{O})$. ESI-MS (pos. mode): $m / z=627.34[\mathrm{M}+\mathrm{Na}]^{+}$. Anal. Calcd for $\mathrm{C}_{36} \mathrm{H}_{48} \mathrm{~N}_{2} \mathrm{O}_{6}(604.79)$ : C, 71.50; H, 8.00; N, 4.63. Found: C, 71.75; H, 8.08; N, 4.54.

\subsection{8. (E)-3-(4-((6-(6-aminohexyl)-2,5,7,8-tetramethylchroman-2-yl)methoxy)} benzylidene)pyrrolidine-2,5-dione hydrochloride (10)

To a solution of compound $9(172 \mathrm{mg}, 0.28 \mathrm{mmol})$ in $\mathrm{CH}_{2} \mathrm{Cl}_{2}(5 \mathrm{~mL})$ was added a saturated solution of $\mathrm{HCl}$ in EtOAc $(5 \mathrm{~mL})$. The mixture was stirred at room temperature for $1 \mathrm{~h}$ and the resulting suspension was filtered and washed with $\mathrm{Et}_{2} \mathrm{O}$, giving after drying $89 \mathrm{mg}(0.16$ mmol, $57 \%$ yield) of white powder. M.p. $250-252^{\circ} \mathrm{C}$. IR $(\mathrm{KBr}) v\left(\mathrm{~cm}^{-1}\right): 3422,3218,2931$, 1774, 1698, 1652, 1602, 1510, 1343, 1249, 1186, 1165, 1117, 1071, 835. ${ }^{1} \mathrm{H}$ NMR (400 MHz, DMSO-d $\left.d_{6}\right): \delta 1.31\left(\mathrm{~s}, 3 \mathrm{H}, \mathrm{CH}_{3}\right), 1.36\left(\mathrm{~m}, 6 \mathrm{H}\right.$, linker $\left.\mathrm{CH}_{2}\right), 1.56\left(\mathrm{~m}, 2 \mathrm{H}\right.$, linker $\left.\mathrm{CH}_{2}\right), 1.86(\mathrm{~m}$, $1 \mathrm{H}$, chromane-3- $\left.H_{a} \mathrm{H}_{\mathrm{b}}\right), 1.98\left(\mathrm{~s}, 3 \mathrm{H}, \mathrm{CH}_{3}\right), 2.03\left(\mathrm{~m}, 1 \mathrm{H}\right.$, chromane-3- $\left.\mathrm{H}_{\mathrm{a}} H_{b}\right), 2.10\left(\mathrm{~s}, 6 \mathrm{H}, \mathrm{CH}_{3}\right.$ x 2), $2.59\left(\mathrm{~m}, 2 \mathrm{H}, \mathrm{CH}_{2}\right), 2.62\left(\mathrm{~m}, 2 \mathrm{H}, \mathrm{CH}_{2}\right), 2.76\left(\mathrm{~m}, 2 \mathrm{H}, \mathrm{CH}_{2}\right), 3.59(\mathrm{~d}, J=2.0 \mathrm{~Hz}, 2 \mathrm{H}$, $\mathrm{CH}_{2} \mathrm{CO}$ ), $4.06\left(\mathrm{~m}, 2 \mathrm{H}, \mathrm{OCH}_{2}\right), 7.06$ (d, J = 8.1 Hz, 2H, $\left.\mathrm{H}_{\text {arom }}\right), 7.33$ (br s, $\left.1 \mathrm{H}, \mathrm{CH}=\mathrm{C}\right), 7.55$ (d, $\left.J=8.1 \mathrm{~Hz}, 2 \mathrm{H}, \mathrm{H}_{\text {arom }}\right), 7.85$ (br s, $\left.3 \mathrm{H}, \mathrm{NH}_{3}{ }^{+}\right), 11.34$ (br s, $\left.1 \mathrm{H}, \mathrm{NH}\right) .{ }^{13} \mathrm{C} \mathrm{NMR}(100 \mathrm{MHz}$, DMSO-d $\left.)_{6}\right): \delta 11.9\left(\mathrm{CH}_{3}\right), 14.6\left(\mathrm{CH}_{3}\right), 15.6\left(\mathrm{CH}_{3}\right), 20.0\left(\mathrm{CH}_{2}\right), 21.6\left(\mathrm{CH}_{3}\right), 25.7\left(\mathrm{CH}_{2}\right), 27.0$ $\left(\mathrm{CH}_{2}\right), 28.1\left(\mathrm{CH}_{2}\right), 29.0\left(\mathrm{CH}_{2}\right), 29.3\left(\mathrm{CH}_{2}\right), 29.6\left(\mathrm{CH}_{2}\right), 34.8\left(\mathrm{CH}_{2}\right), 38.8\left(\mathrm{CH}_{2}\right)$, 72.6, 74.0, $115.3\left(\mathrm{CH}_{\text {arom }}\right), 116.6,121.0,124.1,127.0,130.0,131.0,131.4(\mathrm{CH}=\mathrm{C}), 132.0\left(\mathrm{CH}_{\text {arom }}\right)$, 
132.5, 148.5, 160.0, $172.1(\mathrm{C}=\mathrm{O}), 175.8(\mathrm{C}=\mathrm{O})$. ESI-MS (pos. mode): $\mathrm{m} / z=505.30[\mathrm{M}+\mathrm{H}]^{+}$. Anal. Calcd for $\mathrm{C}_{31} \mathrm{H}_{41} \mathrm{ClN}_{2} \mathrm{O}_{4}, 1 / 2 \mathrm{H}_{2} \mathrm{O}$ (550.14): C, 67.68; H, 7.70; N, 5.09. Found: C, 67.34; $\mathrm{H}, 7.47 ; \mathrm{N}, 5.14$.

$(S)-10$ and $(R)-10$ were prepared in three steps from respectively $(S)-7$ and $(R)-7$. These compounds showed the same spectral data than the racemic compound 10. Specific data: (S)-10: $[\alpha]^{20}{ }_{\mathrm{D}}+11.6$ (c 0.1 in $\left.\mathrm{CHCl}_{3}: \mathrm{MeOH}, 9: 1\right)$. Anal. Calcd for $\mathrm{C}_{31} \mathrm{H}_{41} \mathrm{ClN}_{2} \mathrm{O}_{4},{ }_{2 / 3} \mathrm{H}_{2} \mathrm{O}: \mathrm{C}$, $67.31 ; \mathrm{H}, 7.71 ; \mathrm{N}, 5.06$. Found: C, 67.33; H, 7.54; N, 5.04.

(R)-10: $[\alpha]^{20}{ }_{D}-11.6$ ( $c 0.1$ in $\left.\mathrm{CHCl}_{3}: \mathrm{MeOH}, 9: 1\right)$. Anal. Calcd for $\mathrm{C}_{31} \mathrm{H}_{41} \mathrm{ClN}_{2} \mathrm{O}_{4}, \mathrm{H}_{2} \mathrm{O}: \mathrm{C}$, $66.59 ; \mathrm{H}, 7.75 ; \mathrm{N}, 5.01$. Found: C, 66.53; H, 7.49; N, 4.88.

\subsection{9 methyl 2,5,7,8-tetramethylchromane-2-carboxylate (12)}

A solution of 2,3,5-trimethylphenol $(25.00 \mathrm{~g}, 183.57 \mathrm{mmol})$ in methyl methacrylate $(100 \mathrm{~mL}$, $937.87 \mathrm{mmol})$ was cooled in an ice bath and paraformaldehyde $(6.00 \mathrm{~g}, 199.80 \mathrm{mmol})$ was added. The mixture was stirred under argon for 15 minutes and acetic acid $(5.50 \mathrm{~mL}, 95.99$ mmol) and dibutylamine $(3.80 \mathrm{~mL}, 22.55 \mathrm{mmol})$ were added and the reaction medium was stirred at $0{ }^{\circ} \mathrm{C}$ for further 15 minutes. Ice bath was removed and the mixture was heated at reflux for $48 \mathrm{~h}$. The yellow solution was cooled down to room temperature, and then let at 4 ${ }^{\circ} \mathrm{C}$ for $12 \mathrm{~h}$. The resulting suspension was filtered and the crystals were washed with cooled $\mathrm{MeOH}$ and cooled $\mathrm{Et}_{2} \mathrm{O}$ to give after drying $19.15 \mathrm{~g}$ (77.12 mmol, $42 \%$ yield) of white crystals. M.p. $105-10{ }^{\circ}$ C. IR (ATR): $v\left(\mathrm{~cm}^{-1}\right)$ : 2965, 2920, 1726, 1568, 1447, 1310, 1281, 1206, 1194, 1128, 1109. ${ }^{1} \mathrm{H}$ NMR (400 MHz, $\left.\mathrm{CDCl}_{3}\right): \delta 1.63\left(\mathrm{~s}, 3 \mathrm{H}, \mathrm{CH}_{3}\right), 1.88(\mathrm{~m}, 1 \mathrm{H}$, chromane 3- $\left.\mathrm{H}_{a} \mathrm{H}_{\mathrm{b}}\right), 2.13\left(\mathrm{~s}, 3 \mathrm{H}, \mathrm{CH}_{3}\right), 2.16\left(\mathrm{~s}, 3 \mathrm{H}, \mathrm{CH}_{3}\right), 2.22\left(\mathrm{~s}, 3 \mathrm{H}, \mathrm{CH}_{3}\right), 2.40-2.68(\mathrm{~m}, 3 \mathrm{H}$, chromane $3-\mathrm{H}_{\mathrm{a}} \mathrm{H}_{b}+$ chromane $\left.4-\mathrm{CH}_{2}\right), 3.69\left(\mathrm{~s}, 3 \mathrm{H}, \mathrm{OCH}_{3}\right), 6.58\left(\mathrm{~s}, 1 \mathrm{H}, \mathrm{H}_{\text {arom }}\right) .{ }^{13} \mathrm{C} \mathrm{NMR}(100$ $\left.\mathrm{MHz}, \mathrm{CDCl}_{3}\right): \delta 11.5\left(\mathrm{CH}_{3}\right), 18.8\left(\mathrm{CH}_{3}\right), 19.8\left(\mathrm{CH}_{3}\right), 20.5\left(\mathrm{CH}_{2}\right), 25.6\left(\mathrm{CH}_{3}\right), 30.4\left(\mathrm{CH}_{2}\right)$, $52.5\left(\mathrm{OCH}_{3}\right), 77.5,116.5,122.0,123.4\left(\mathrm{CH}_{\text {arom }}\right), 133.3,135.0,151.5,174.5(\mathrm{C}=\mathrm{O})$. ESI-MS (pos. mode): $m / z=271.14[\mathrm{M}+\mathrm{Na}]^{+}$. Anal. Calcd for $\mathrm{C}_{15} \mathrm{H}_{20} \mathrm{O}_{3}(248.14): \mathrm{C}, 72.55 ; \mathrm{H}, 8.12$. Found: C, 72.69; H, 8.16.

\subsubsection{0 methyl 6-(6-bromohexanoyl)-2,5,7,8-tetramethylchromane-2-carboxylate (13)}

Preparation of the intermediate acyl chloride: a solution of 6-bromohexanoic acid (19.60 g, $100 \mathrm{mmol})$ and thionyl chloride $(21.6 \mathrm{~mL}, 291 \mathrm{mmol})$ in dry $\mathrm{CH}_{2} \mathrm{Cl}_{2}(50 \mathrm{~mL})$ was refluxed under argon for 3 hours. The solvent was removed under vacuum for $3 \mathrm{~h}$ to remove the excess of thionyl chloride. The resulting colorless liquid was then dissolved in $\mathrm{CH}_{2} \mathrm{Cl}_{2}(15 \mathrm{~mL})$ and formic acid $(0.75 \mathrm{~mL}, 20.00 \mathrm{mmol})$ was added to remove the last traces of thionyl chloride. The mixture was stirred $2 \mathrm{~h}$ at room temperature until no bubbling occurred and used without further purification.

Friedel-Crafts acylation: To the above solution were added $\mathrm{AlCl}_{3}(10.50 \mathrm{~g}, 78.00 \mathrm{mmol})$ and anhydrous dichloromethane (10 mL). A solution of $12(5.00 \mathrm{~g}, 20.13 \mathrm{mmol})$ in $\mathrm{CH}_{2} \mathrm{Cl}_{2}(35$ $\mathrm{mL}$ ) was then added dropwise in 20 minutes at $0{ }^{\circ} \mathrm{C} .15$ minutes after the end of the addition were added EtOAc $(250 \mathrm{~mL})$ and water $(80 \mathrm{~mL})$. The organic layer was then washed twice with water $(80 \mathrm{~mL})$, and with a $5 \%$ aqueous solution of potassium bicarbonate $(10 \times 30 \mathrm{~mL})$ to remove the excess of hydrolyzed acyl chloride, and then with water $(50 \mathrm{~mL})$. The organic layer was dried $\left(\mathrm{MgSO}_{4}\right)$, filtered and concentrated under vacuum to give a brownish liquid which was further purified by column chromatography (eluent: cyclohexane/EtOAc, 100/0 to 
88/12) to afford $6.00 \mathrm{~g}$ (14.11 mmol, $70 \%$ yield $)$ of a colorless liquid which crystallized upon storage at $4{ }^{\circ}$ C. M.p. $68-70{ }^{\circ}$ C. IR (ATR): $v\left(\mathrm{~cm}^{-1}\right)$ : 2930, 2864, 1746, 1693, 1460, 1435 , 1240, 1138, 1111. ${ }^{1} \mathrm{H}$ NMR $\left(400 \mathrm{MHz}, \mathrm{CDCl}_{3}\right): \delta 1.51\left(\mathrm{~m}, 2 \mathrm{H}\right.$, linker- $\left.\mathrm{CH}_{2}\right), 1.61(\mathrm{~s}, 3 \mathrm{H}$, $\left.\mathrm{CH}_{3}\right), 1.73\left(\mathrm{~m}, 2 \mathrm{H}\right.$, linker- $\left.\mathrm{CH}_{2}\right), 1.79-1.95\left(\mathrm{~m}, 3 \mathrm{H}\right.$, linker- $\mathrm{CH}_{2}+$ chromane $\left.3-H_{a} \mathrm{H}_{\mathrm{b}}\right), 1.98(\mathrm{~s}$, $\left.3 \mathrm{H}, \mathrm{CH}_{3}\right), 2.06\left(\mathrm{~s}, 3 \mathrm{H}, \mathrm{CH}_{3}\right), 2.14\left(\mathrm{~s}, 3 \mathrm{H}, \mathrm{CH}_{3}\right), 2.39-2.50\left(\mathrm{~m}, 2 \mathrm{H}\right.$, chromane $4-\mathrm{H}_{a} \mathrm{H}_{\mathrm{b}}+$ chromane $\left.3-\mathrm{H}_{\mathrm{a}} H_{b}\right), 2.60\left(\mathrm{~m}, 1 \mathrm{H}\right.$, chromane $\left.4-\mathrm{H}_{\mathrm{a}} H_{b}\right), 2.67\left(\mathrm{t}, J=7.3 \mathrm{~Hz}, 2 \mathrm{H}, \mathrm{CH}_{2} \mathrm{CO}\right), 3.42(\mathrm{t}$, $\left.J=6.6 \mathrm{~Hz}, 2 \mathrm{H}, \mathrm{CH}_{2} \mathrm{Br}\right), 3.67\left(\mathrm{~s}, 3 \mathrm{H}, \mathrm{OCH}_{3}\right) .{ }^{13} \mathrm{C} \mathrm{NMR}\left(100 \mathrm{MHz}, \mathrm{CDCl}_{3}\right): \delta 11.5\left(\mathrm{CH}_{3}\right)$, $15.7\left(\mathrm{CH}_{3}\right), 16.7\left(\mathrm{CH}_{3}\right), 20.6\left(\mathrm{CH}_{2}\right), 22.7\left(\mathrm{CH}_{2}\right), 25.5\left(\mathrm{CH}_{3}\right), 27.9\left(\mathrm{CH}_{2}\right), 30.4\left(\mathrm{CH}_{2}\right), 32.8$ $\left(\mathrm{CH}_{2}\right), 33.7\left(\mathrm{CH}_{2}\right), 45.6\left(\mathrm{CH}_{2}\right), 52.6\left(\mathrm{OCH}_{3}\right), 77.5\left(\mathrm{C}_{\text {quat }}\right), 117.1,122.9,128.0,129.7,135.6$, 151.6, 174.1 (ester $\mathrm{C}=\mathrm{O}$ ), 211.5 (ketone $\mathrm{C}=\mathrm{O}$ ). ESI-MS (pos. mode): $\mathrm{m} / z=447.12[\mathrm{M}+\mathrm{Na}$, $\left.{ }^{79} \mathrm{Br}\right]^{+}, 449.12\left[\mathrm{M}+\mathrm{Na},{ }^{81} \mathrm{Br}\right]^{+}$. Anal. Calcd for $\mathrm{C}_{21} \mathrm{H}_{29} \mathrm{BrO}_{4}$ (425.36): C, 59.30; H, 6.87. Found: C, 59.36; H, 6.87 .

\subsubsection{1 (6-(6-bromohexyl)-2,5,7,8-tetramethylchroman-2-yl)methanol (14)}

To a suspension of $\mathrm{LiAlH}_{4}(1.82 \mathrm{~g}, 48.00 \mathrm{mmol})$ in dry $\mathrm{Et}_{2} \mathrm{O}(30 \mathrm{~mL})$ under argon was added $\mathrm{AlCl}_{3}(4.27 \mathrm{~g}, 32.02 \mathrm{mmol})$. Five minutes later, a solution of $\mathrm{AlCl}_{3}(2.14 \mathrm{~g}, 16.05 \mathrm{mmol})$ and 13 (6.82 g, $16.03 \mathrm{mmol})$ in dry $\mathrm{Et}_{2} \mathrm{O}(90 \mathrm{~mL})$ was slowly added. The mixture was stirred under argon at room temperature for $2 \mathrm{~h}$, and the reaction was then quenched with cold water (140 $\mathrm{mL}$ ) and $6 \mathrm{M}$ aqueous $\mathrm{H}_{2} \mathrm{SO}_{4}$ solution $(80 \mathrm{~mL})$. The aqueous layer was extracted twice with EtOAc $(100 \mathrm{~mL})$, and the combined organic layers were washed with $2 \mathrm{M} \mathrm{Na}_{2} \mathrm{CO}_{3}$ aqueous solution $(70 \mathrm{~mL})$, dried $\left(\mathrm{MgSO}_{4}\right)$ and the solvent was removed under vacuum to give a yellow liquid which was purified by column chromatography (eluent: cyclohexane/EtOAc, $100 / 0$ to $88 / 12)$ to afford $4.42 \mathrm{~g}(11.5 \mathrm{mmol}, 72 \%$ yield $)$ of colorless liquid. ${ }^{1} \mathrm{H}$ NMR (200 $\left.\mathrm{MHz}, \mathrm{CDCl}_{3}\right): \delta 1.23\left(\mathrm{~s}, 3 \mathrm{H}, \mathrm{CH}_{3}\right), 1.46\left(\mathrm{~m}, 6 \mathrm{H}\right.$, linker $\left.\mathrm{CH}_{2}\right), 1.66-2.08\left(\mathrm{~m}, 5 \mathrm{H}\right.$, linker $\mathrm{CH}_{2}+$ chromane 3- $\left.\mathrm{CH}_{2}+\mathrm{CH}_{2} \mathrm{OH}\right), 2.12\left(\mathrm{~s}, 3 \mathrm{H}, \mathrm{CH}_{3}\right), 2.17\left(\mathrm{~s}, 3 \mathrm{H}, \mathrm{CH}_{3}\right), 2.21\left(\mathrm{~s}, 3 \mathrm{H}, \mathrm{CH}_{3}\right), 2.55-$ $2.79\left(\mathrm{~m}, 4 \mathrm{H}\right.$, linker $\mathrm{CH}_{2}+$ chromane $\left.4-\mathrm{CH}_{2}\right), 3.43\left(\mathrm{t}, J=6.8 \mathrm{~Hz}, 2 \mathrm{H}, \mathrm{CH}_{2} \mathrm{Br}\right), 3.58,3.68$ (AB system, $\left.J=11.4 \mathrm{~Hz}, 2 \mathrm{H}, \mathrm{CH}_{2} \mathrm{OH}\right)$. Other analyses were in accordance with published results [13].

\subsubsection{2. (6-(6-azidohexyl)-2,5,7,8-tetramethylchroman-2-yl)methanol (15)}

A solution of $14(4.81 \mathrm{~g}, 12.55 \mathrm{mmol})$ and $\mathrm{NaN}_{3}(1.63 \mathrm{~g}, 25.1 \mathrm{mmol})$ in dry DMF (50 mL) was heated at $80{ }^{\circ} \mathrm{C}$ for $3 \mathrm{~h}$. The mixture was cooled to room temperature then diluted with EtOAc $(60 \mathrm{~mL})$, washed with water $(5 \times 30 \mathrm{~mL})$ and with brine $(2 \times 30 \mathrm{~mL})$. The organic layer was then dried $\left(\mathrm{MgSO}_{4}\right)$, and the solvent was removed under vacuum to afford $3.76 \mathrm{~g}$ (10.88 mmol, 87\% yield) of $\mathbf{1 5}$ as a colorless liquid which was used without further purification. ${ }^{1} \mathrm{H}$ NMR $\left(200 \mathrm{MHz}, \mathrm{CDCl}_{3}\right): \delta 1.23\left(\mathrm{~s}, 3 \mathrm{H}\right.$, chromane $\left.\mathrm{CH}_{3}\right), 1.45(\mathrm{~m}, 6 \mathrm{H}$, linker $\left.\mathrm{CH}_{2}\right), 1.54-1.82\left(\mathrm{~m}, 4 \mathrm{H}\right.$, linker $\mathrm{CH}_{2}+$ chromane $\left.3-\mathrm{H}_{a} \mathrm{H}_{\mathrm{b}}+\mathrm{CH}_{2} \mathrm{OH}\right), 1.98(\mathrm{~m}, 1 \mathrm{H}$, chromane 3- $\left.\mathrm{H}_{\mathrm{a}} \mathrm{H}_{b}\right), 2.12\left(\mathrm{~s}, 3 \mathrm{H}, \mathrm{CH}_{3}\right), 2.17\left(\mathrm{~s}, 3 \mathrm{H}, \mathrm{CH}_{3}\right), 2.21\left(\mathrm{~s}, 3 \mathrm{H}, \mathrm{CH}_{3}\right), 2.66\left(\mathrm{~m}, 4 \mathrm{H}\right.$, linker $\mathrm{CH}_{2}+$ chromane 4- $\left.\mathrm{CH}_{2}\right), 3.28\left(\mathrm{t}, J=6.8 \mathrm{~Hz}, 2 \mathrm{H}, \mathrm{CH}_{2} \mathrm{~N}_{3}\right), 3.62\left(\mathrm{~m}, 2 \mathrm{H}, \mathrm{CH}_{2} \mathrm{O}\right)$. Other analyses were in accordance with published results [13].

\subsubsection{3. (6-(6-aminohexyl)-2,5,7,8-tetramethylchroman-2-yl)methanol (16)}


In a round bottom flask was first introduced $10 \%$ palladium on carbon $(352 \mathrm{mg}$ ), in order to avoid any ignition of the solvent. A solution of 15 (3.52 g, $10.19 \mathrm{mmol})$ in EtOAc (30 mL) was then added. The mixture was stirred under a hydrogen atmosphere for $18 \mathrm{~h}$ at room temperature, then filtered on celite ${ }^{\circledR}$, and the resulting solution was concentrated. Column chromatography (eluent: $\mathrm{CH}_{2} \mathrm{Cl}_{2}\left(+1 \% \mathrm{Et}_{3} \mathrm{~N}\right) / \mathrm{MeOH}, 100 / 0$ to $90 / 10$ in 10 minutes, then 30 minutes in isocratic mode) afforded $2.61 \mathrm{~g}(8.17 \mathrm{mmol}, 80 \%$ yield $)$ of slightly yellow liquid. IR (ATR): 2920, 2851, 1570, 1449, 1312, 1105, 1063. ${ }^{1} \mathrm{H}$ NMR (400 MHz, $\mathrm{CDCl}_{3}$ ): $\delta 1.23$ (s, $\left.3 \mathrm{H}, \mathrm{CH}_{3}\right), 1.43\left(\mathrm{~m}, 6 \mathrm{H}\right.$, linker $\left.\mathrm{CH}_{2}\right), 1.48\left(\mathrm{~m}, 2 \mathrm{H}\right.$, linker $\left.\mathrm{CH}_{2}\right), 1.74(\mathrm{~m}, 1 \mathrm{H}$, chromane 3$\left.H_{a} \mathrm{H}_{\mathrm{b}}\right), 2.00\left(\mathrm{~m}, 3 \mathrm{H}\right.$, chromane $\left.3-\mathrm{H}_{\mathrm{a}} \mathrm{H}_{b}+\mathrm{NH}_{2}\right), 2.12\left(\mathrm{~s}, 3 \mathrm{H}, \mathrm{CH}_{3}\right), 2.16\left(\mathrm{~s}, 3 \mathrm{H}, \mathrm{CH}_{3}\right), 2.20(\mathrm{~s}$, $\left.3 \mathrm{H}, \mathrm{CH}_{3}\right), 2.58-2.75\left(\mathrm{~m}, 6 \mathrm{H}\right.$, chromane 4- $\mathrm{CH}_{2}+$ linker $\left.\mathrm{CH}_{2}+\mathrm{CH}_{2} \mathrm{NH}_{2}\right), 3.58,3.65(\mathrm{AB}$ system, $\left.2 \mathrm{H}, J=11.3 \mathrm{~Hz}, \mathrm{CH}_{2} \mathrm{OH}\right) .{ }^{13} \mathrm{C} \mathrm{NMR}\left(100 \mathrm{MHz}, \mathrm{CDCl}_{3}\right): \delta 12.2\left(\mathrm{CH}_{3}\right), 15.1\left(\mathrm{CH}_{3}\right)$, $16.0\left(\mathrm{CH}_{3}\right), 20.7$ (2 pics: $\left.\mathrm{CH}_{3}+\mathrm{CH}_{2}\right), 26.9\left(\mathrm{CH}_{2}\right), 28.0\left(\mathrm{CH}_{2}\right), 30.1\left(\mathrm{CH}_{2}\right), 30.3\left(\mathrm{CH}_{2}\right), 33.2$ $\left(\mathrm{CH}_{2}\right), 40.7\left(\mathrm{CH}_{2}\right), 42.0\left(\mathrm{CH}_{2}\right), 69.6,75.3,117.0,122.2,131.1,131.8,133.5,149.0$. ESI-MS (pos. mode): $\mathrm{m} / \mathrm{z}=320.26[\mathrm{M}+\mathrm{H}]^{+}$. Anal. Calcd for $\mathrm{C}_{20} \mathrm{H}_{33} \mathrm{NO}_{2}, 1 / 4 \mathrm{H}_{2} \mathrm{O}$ (323.99): C, 74.14; H, 10.42; N, 4.32. Found: C, 74.42; H, 10.32; N, 4.41.

\subsubsection{4 tert-butyl (6-(2-(hydroxymethyl)-2,5,7,8-tetramethylchroman-6-yl)hexyl)carbamate (7)}

To a solution of compound $16(1.59 \mathrm{~g}, 4.98 \mathrm{mmol})$ in dry $\mathrm{CH}_{2} \mathrm{Cl}_{2}(15 \mathrm{~mL})$ was added under stirring at room temperature $\mathrm{Boc}_{2} \mathrm{O}(773 \mu \mathrm{L}, 5.0 \mathrm{mmol})$. After 45 minutes, the solvent was removed under vacuum, and the crude product was diluted in EtOAc $(20 \mathrm{~mL})$, the solution was washed with an aqueous $5 \%$ citric acid solution $(2 \times 20 \mathrm{~mL})$, water $(10 \mathrm{~mL})$, and brine $(10 \mathrm{~mL})$. The organic layer was dried $\left(\mathrm{MgSO}_{4}\right)$ and the solvent was removed under vacuum to afford a yellow liquid which was purified by column chromatography (eluent: cyclohexane/EtOAc, $100 / 0$ to $80 / 20$ in 20 minutes then 20 minutes in isocratic mode) to afford 7 (2.08 g, $4.96 \mathrm{mmol}, 100 \%$ yield) as a colorless liquid. ${ }^{1} \mathrm{H}$ NMR (400 MHz, $\mathrm{CDCl}_{3}$ ): $1.23\left(\mathrm{~s}, 3 \mathrm{H}, \mathrm{CH}_{3}\right), 1.45(\mathrm{~s}, 9 \mathrm{H}, t-\mathrm{Bu}), 1.36-1.53\left(\mathrm{~m}, 6 \mathrm{H}\right.$, linker $\left.\mathrm{CH}_{2}\right), 1.64$ (br s, 3H, linker $\left.\mathrm{CH}_{2}+\mathrm{CH}_{2} \mathrm{OH}\right), 1.72\left(\mathrm{~m}, 1 \mathrm{H}\right.$, chromane $\left.3-H_{a} \mathrm{H}_{\mathrm{b}}\right), 2.01\left(\mathrm{~m}, 1 \mathrm{H}\right.$, chromane $\left.3-\mathrm{H}_{\mathrm{a}} H_{b}\right), 2.12(\mathrm{~s}$, $\left.3 \mathrm{H}, \mathrm{CH}_{3}\right), 2.16\left(\mathrm{~s}, 3 \mathrm{H}, \mathrm{CH}_{3}\right), 2.20\left(\mathrm{~s}, 3 \mathrm{H}, \mathrm{CH}_{3}\right), 2.57-2.70\left(\mathrm{~m}, 4 \mathrm{H}\right.$, chromane 4- $\mathrm{CH}_{2}+$ linker $\mathrm{CH}_{2}$ ), 3.12 (t, $J=6.2 \mathrm{~Hz}, \mathrm{CH}_{2} \mathrm{NHBoc}$ ), 3.59, 3.65 (AB system, $J=11.2 \mathrm{~Hz}, 2 \mathrm{H}, \mathrm{CH}_{2} \mathrm{OH}$ ), 4.48 (br s, 1H, NHBoc). Other analyses were in accordance with published results [13].

\subsubsection{Deracemization of compound 7}

\subsubsection{Preparation of the supported Lipase}

According to Couladouros et al. [17], lipase PS-30 (3 g) and Hyflo Supercel ${ }^{\circledR}$ (10 g) were added to a buffered solution $(10 \mathrm{~mL})$ of $\mathrm{Na}_{2} \mathrm{HPO}_{4}(117.12 \mathrm{mg})$ and $\mathrm{KH}_{2} \mathrm{PO}_{4}(82.66 \mathrm{mg})$ in distilled water $(30 \mathrm{~mL}, \mathrm{pH}$ 7). The suspension was shaken vigorously then dried under high vacuum for $24 \mathrm{~h}$. 


\subsubsection{2. (S)-4-((6-(6-((tert-butoxycarbonyl)amino)hexyl)-2,5,7,8-tetramethylchroman-2-}

yl)methoxy)-4-oxobutanoic acid: ((S)-enriched 19), first lipase reaction.

To a stirred solution of $7(1.00 \mathrm{~g}, 2.38 \mathrm{mmol})$ in MTBE $(6 \mathrm{~mL})$ were added succinic anhydride (346 mg, $3.46 \mathrm{mmol}$ ) and supported Amano Lipase PS (720 mg). After $18 \mathrm{~h}$ of stirring at room temperature, the precipitate was filtered, washed with MTBE ( $5 \mathrm{~mL})$ and the filtrate was evaporated under reduced pressure. The residue was purified by flash column chromatography (eluent: cyclohexane/EtOAc 100/0 to 80/20 in 20 minutes, then 20 minutes in isocratic mode) to give $415 \mathrm{mg}$ of $(R)$-enriched 7 (0.98 mmol, $44 \%$ yield) as a white powder and $600 \mathrm{mg}$ of $(S)$-enriched $19(1.15 \mathrm{mmol}, 52 \%$ yield) as a slightly trouble liquid. IR (ATR) $v\left(\mathrm{~cm}^{-1}\right): 3342,2974,2924,2851,1736,1711,1649,1572,1510,1448,1366,1246 .{ }^{1} \mathrm{H}$ NMR (400 MHz, $\left.\mathrm{CDCl}_{3}\right): \delta 1.29\left(\mathrm{~s}, 3 \mathrm{H}, \mathrm{CH}_{3}\right), 1.43(\mathrm{~s}, 9 \mathrm{H}, t-\mathrm{Bu}), 1.33-1.52(\mathrm{~m}, 8 \mathrm{H}$, linker $\left.\mathrm{CH}_{2}\right), 1.79\left(\mathrm{~m}, 1 \mathrm{H}\right.$, chromane $\left.3-H_{a} \mathrm{H}_{\mathrm{b}}\right), 1.93\left(\mathrm{~m}, 1 \mathrm{H}\right.$, chromane $\left.3-\mathrm{H}_{\mathrm{a}} \mathrm{H}_{b}\right), 2.09\left(\mathrm{~s}, 3 \mathrm{H}, \mathrm{CH}_{3}\right)$, $2.14\left(\mathrm{~s}, 3 \mathrm{H}, \mathrm{CH}_{3}\right), 2.19\left(\mathrm{~s}, 3 \mathrm{H}, \mathrm{CH}_{3}\right), 2.56-2.70\left(\mathrm{~m}, 8 \mathrm{H}\right.$, succinate $\mathrm{CH}_{2}$ x $2+$ chromane 4- $\mathrm{CH}_{2}$ + linker $\mathrm{CH}_{2}$ ), $3.11\left(\mathrm{~m}, 2 \mathrm{H}, \mathrm{CH}_{2} \mathrm{NHBoc}\right), 4.09,4.21$ (AB system, $J=11.2 \mathrm{~Hz}, 2 \mathrm{H}, \mathrm{CH}_{2} \mathrm{O}$ ), 4.52 (br s, $1 \mathrm{H}, \mathrm{NHBoc}) .{ }^{13} \mathrm{C} \mathrm{NMR}\left(100 \mathrm{MHz}, \mathrm{CDCl}_{3}\right)$ : $\delta 12.1\left(\mathrm{CH}_{3}\right), 15.0\left(\mathrm{CH}_{3}\right), 16.0\left(\mathrm{CH}_{3}\right)$, $20.7\left(\mathrm{CH}_{2}\right), 22.2\left(\mathrm{CH}_{3}\right), 26.8\left(\mathrm{CH}_{2}\right), 27.1\left(\mathrm{CH}_{2}\right), 28.6(t-\mathrm{Bu}), 28.9\left(\mathrm{CH}_{2}\right), 29.1\left(\mathrm{CH}_{2}\right), 29.9$ $\left(\mathrm{CH}_{2}\right), 30.1\left(\mathrm{CH}_{2}\right), 30.2\left(\mathrm{CH}_{2}, 2\right.$ peaks $), 40.8\left(\mathrm{CH}_{2}\right), 69.3,73.4,116.7,122.4,131.0,131.5$, 133.4, 149.1, 172.0, 176.6. ESI-MS (pos. mode): $m / z=542.31[\mathrm{M}+\mathrm{Na}]^{+}$. Anal. Calcd for $\mathrm{C}_{29} \mathrm{H}_{45} \mathrm{NO}_{7}$ (519.68): C, 67.03; H, 8.73; N, 2.70. Found: C, 66.95; H, 8.88; N, 2.56.

\subsubsection{General procedure for the saponification of 19.}

To a stirred solution of $(S)$-enriched 19 in a 1:1 mixture of THF and $\mathrm{MeOH}(10 \mathrm{~mL}$ per mmol) was added a $3 \mathrm{M}$ aqueous solution of $\mathrm{LiOH}$ (3.0 eq). After 30 minutes of stirring at room temperature, the reaction mixture was quenched with a saturated aqueous solution of $\mathrm{NH}_{4} \mathrm{Cl}(10 \mathrm{~mL})$, and diluted in EtOAc $(25 \mathrm{~mL}$ per mmol). The solution was washed with distilled water ( $3 \times 15 \mathrm{~mL}$ per mmol), the organic layer was dried $\left(\mathrm{MgSO}_{4}\right)$, and the solvent was removed under vacuum to afford $(S)$-enriched 7 which was used without further purification. The NMR spectrum was in accordance with the expected data.

\subsubsection{General procedure for the resolution of the racemic compound 7 (second and third} lipase reactions).

Both $(S)$-enriched compound 7 and $(R)$-enriched compound 7 were subjected twice to the same procedure as before. The final yields after the three enzymatic resolutions are given below, taking into account that the maximum theoretical yield for each is $50 \%$. The resolved compounds exhibited identical spectroscopic data to the racemic alcohol 7.

(S)-7 : Yield : $22 \%[\alpha]^{20}{ }_{\mathrm{D}}+1.1^{\circ}\left(c 0.1\right.$ in $\left.\mathrm{CHCl}_{3}\right)$, ee $=98 \%$

(R)-7 : Yield : $23 \%,[\alpha]^{20}-1.1^{\circ}\left(c 0.1\right.$ in $\left.\mathrm{CHCl}_{3}\right)$, ee $=98 \%$

\subsubsection{General procedure for the measurement of enantiomeric excess of 7.}

According to reported procedure [20], in a NMR tube was introduced a solution of 7 (3-7 mg, $7.15 \mu \mathrm{mol}-16.68 \mu \mathrm{mol})$ in $\mathrm{C}_{5} \mathrm{D}_{5} \mathrm{~N}(0.1 \mathrm{~mL})$ and $\mathrm{CDCl}_{3}(0.1 \mathrm{~mL})$, and $(R)$-Mosher acyl chloride $(5 \mu \mathrm{L}, 26.72 \mu \mathrm{mol})$ was added. After $3 \mathrm{~h}$ reaction, $\mathrm{C}_{6} \mathrm{D}_{6}(0.5 \mathrm{~mL})$ and $\mathrm{CDCl}_{3}(0.1$ $\mathrm{mL}$ ) were added. The NMR signals of interest are displayed in the 4.00-4.35 area as two AB systems for both diastereomers. 


\subsubsection{Verification of the conservation of the enantiomeric excess in acidic conditions}

\subsubsection{1. (S)-(6-(6-aminohexyl)-2,5,7,8-tetramethylchroman-2-yl)methyl acetate hydrochloride ((S)-21).}

To a stirred solution of $(S)-7(100 \mathrm{mg}, 0.24 \mathrm{mmol})$ in dry $\mathrm{CH}_{2} \mathrm{Cl}_{2}(6 \mathrm{~mL})$ were added $\mathrm{Ac}_{2} \mathrm{O}$ ( $24 \mu \mathrm{L}, 0.26 \mathrm{mmol})$, pyridine $(21 \mu \mathrm{L}, 0.26 \mathrm{mmol})$ and DMAP ( $3 \mathrm{mg}, 0.024 \mathrm{mmol})$. The mixture was stirred under argon for $16 \mathrm{~h}$ and the solvents were removed under reduced pressure. The crude product was dissolved in dry $\mathrm{CH}_{2} \mathrm{Cl}_{2}(4 \mathrm{~mL})$ and a $1.5 \mathrm{M}$ solution of $\mathrm{HCl}$ in EtOAc was added $(2 \mathrm{~mL}, 3.0 \mathrm{mmol})$. After $3 \mathrm{~h}$ stirring at room temperature, the solvents were removed under reduced pressure, and the $\mathrm{HCl}$ was co-evaporated twice with $\mathrm{CH}_{2} \mathrm{Cl}_{2}$ to give a pale-yellow powder, which was suspended in $\mathrm{CH}_{2} \mathrm{Cl}_{2}$, filtered, washed with $\mathrm{Et}_{2} \mathrm{O}(2 \times 5$ $\mathrm{mL})$ and with $\mathrm{CH}_{2} \mathrm{Cl}_{2}(2 \times 2 \mathrm{~mL})$ to give $87 \mathrm{mg}(0.22 \mathrm{mmol}, 92 \%$ yield $)$ of white powder. M.p.: $130-132{ }^{\circ} \mathrm{C}$. IR (ATR): $v\left(\mathrm{~cm}^{-1}\right)$ 2920, 1732, 1658, 1520, 1383, 1240. ${ }^{1} \mathrm{H}$ NMR (400 $\mathrm{MHz}_{\mathrm{CDCl}}$ ): $\delta 1.28\left(\mathrm{~s}, 3 \mathrm{H}, \mathrm{CH}_{3}\right), 1.45\left(\right.$ br s, $6 \mathrm{H}$, linker $\left.\mathrm{CH}_{2}\right), 1.80(\mathrm{~m}, 3 \mathrm{H}$, chromane 3$H_{a} \mathrm{H}_{\mathrm{b}}+$ linker $\left.\mathrm{CH}_{2}\right), 1.93\left(\mathrm{~m}, 1 \mathrm{H}\right.$, chromane 3- $\left.\mathrm{H}_{\mathrm{a}} \mathrm{H}_{b}\right), 2.08\left(\mathrm{~s}, 3 \mathrm{H}, \mathrm{CH}_{3}\right), 2.09\left(\mathrm{~s}, 3 \mathrm{H}, \mathrm{CH}_{3}\right)$, $2.14\left(\mathrm{~s}, 3 \mathrm{H}, \mathrm{CH}_{3}\right), 2.18\left(\mathrm{~s}, 3 \mathrm{H}, \mathrm{CH}_{3}\right), 2.55-2.67\left(\mathrm{~m}, 4 \mathrm{H}\right.$, chromane 4- $\left.\mathrm{CH}_{2}+\operatorname{linker} \mathrm{CH}_{2}\right), 3.00$ (m, $2 \mathrm{H}, \mathrm{CH}_{2} \mathrm{NH}_{3}{ }^{+}$), 4.07, $4.15\left(\mathrm{AB}\right.$ system, $\left.J=11.2 \mathrm{~Hz}, 2 \mathrm{H}, \mathrm{CH}_{2} \mathrm{O}\right), 8.28$ (br s, $3 \mathrm{H}, \mathrm{NH}_{3}{ }^{+}$). ${ }^{13} \mathrm{C} \mathrm{NMR}\left(100 \mathrm{MHz}, \mathrm{CDCl}_{3}\right): \delta 12.1\left(\mathrm{CH}_{3}\right), 15.0\left(\mathrm{CH}_{3}\right), 16.0\left(\mathrm{CH}_{3}\right), 20.6\left(\mathrm{CH}_{2}\right), 21.0\left(\mathrm{CH}_{3}\right)$, $21.9\left(\mathrm{CH}_{3}\right), 26.6\left(\mathrm{CH}_{2}\right), 27.9\left(\mathrm{CH}_{2}\right), 28.7\left(\mathrm{CH}_{2}\right), 29.6\left(\mathrm{CH}_{2}\right), 30.0\left(\mathrm{CH}_{2}\right), 30.1\left(\mathrm{CH}_{2}\right), 40.1$ $\left(\mathrm{CH}_{2}\right), 69.0,73.5,116.6,122.4,130.6,131.5,133.4,149.1,171.0(\mathrm{C}=\mathrm{O})$. ESI-MS (pos. mode): $\mathrm{m} / z=362.27[\mathrm{M}]^{+}$. Anal. Calcd for $\mathrm{C}_{22} \mathrm{H}_{36} \mathrm{ClNO}_{3}$ (397.98): C, 66.40; H, 9.12; N, 3.52. Found: C, 66.28; H, 9.15; N, 3.48.

\subsubsection{Recovery of compound (S)-7 after acidic treatment: conservation the absolute configuration.}

To a solution of $(S)-21(55 \mathrm{mg}, 0.14 \mathrm{mmol})$ in dry $\mathrm{CH}_{2} \mathrm{Cl}_{2}(2 \mathrm{~mL})$ were added $\mathrm{Et}_{3} \mathrm{~N}(195 \mu \mathrm{L}$, $1.4 \mathrm{mmol})$ and $\mathrm{Boc}_{2} \mathrm{O}(61 \mathrm{mg}, 0.28 \mathrm{mmol})$ at room temperature. The mixture was stirred for 2 $\mathrm{h}$, and the solvent was removed under reduced pressure. The crude product was diluted in a 1:1 mixture of THF and $\mathrm{MeOH}(4 \mathrm{~mL})$ and an aqueous solution of $3 \mathrm{M} \mathrm{LiOH}(0.23 \mathrm{~mL}, 0.70$ mmol) was added. After $1 \mathrm{~h}$ stirring at room temperature, the reaction was quenched by addition of a saturated solution of $\mathrm{NH}_{4} \mathrm{Cl}(10 \mathrm{~mL})$, diluted with EtOAc $(50 \mathrm{~mL})$ and washed with water $(3 \times 10 \mathrm{~mL})$. The organic layer was dried $\left(\mathrm{MgSO}_{4}\right)$ and the solvent was removed under reduce pressure. The residue was purified by column chromatography (eluent: cyclohexane/EtOAc 100/0 to 30/70 in 20 minutes) to give $53 \mathrm{mg}$ of colorless liquid (0.13 mmol, 93\% yield). This compound exhibited the same spectral data than the previously described molecule 7. Furthermore, its optical rotation and the deduced ee after reaction with $(R)$-Mosher acyl chloride were identical to starting compound $(\boldsymbol{S})-\mathbf{7}$.

\subsubsection{4-((6-(6-azidohexyl)-2,5,7,8-tetramethylchroman-2-yl)methoxy)benzaldehyde (27)} Preparation of the triflate intermediate: to an ice cooled solution of anhydrous pyridine (1.15 $\mathrm{mL}, 14.29 \mathrm{mmol})$ in dry $\mathrm{CH}_{2} \mathrm{Cl}_{2}(10 \mathrm{~mL})$ was added dropwise trifluoromethanesulfonic anhydride $(560 \mu \mathrm{L}, 3.3 \mathrm{mmol})$ under argon. A solution of $15(822 \mathrm{mg}, 2.38 \mathrm{mmol})$ in $\mathrm{CH}_{2} \mathrm{Cl}_{2}$ $(10 \mathrm{~mL})$ was added 5 minutes later to the reaction mixture. The solution was stirred for 30 
minutes at $0{ }^{\circ} \mathrm{C}$ and the solvent was evaporated. The residue was dissolved in EtOAc (30 $\mathrm{mL})$, the solution was washed with water $(3 \times 20 \mathrm{~mL}), 5 \%$ aqueous $\mathrm{NaHCO}_{3}$ solution $(3 \times 20$ $\mathrm{mL})$, and brine $(3 \times 20 \mathrm{~mL})$. The organic phase was then dried $\left(\mathrm{MgSO}_{4}\right)$ and the solvent was removed under vacuum to afford an orange liquid.

Condensation with 4-hydroxybenzaldehyde: to a solution of the above triflate in dry DMF (5 $\mathrm{mL}$ ) were added 4-hydroxybenzaldehyde (291 mg, $2.38 \mathrm{mmol})$ and $\mathrm{K}_{2} \mathrm{CO}_{3}(658 \mathrm{mg}, 4.76$ $\mathrm{mmol})$. The reaction mixture was stirred under argon at room temperature for 5 days, and then EtOAc $(50 \mathrm{~mL})$ was added. The organic layer was washed with water $(5 \times 20 \mathrm{~mL}), 5 \%$ aqueous $\mathrm{NaHCO}_{3}$ solution $(2 \times 20 \mathrm{~mL})$, water $(2 \times 20 \mathrm{~mL})$, dried $\left(\mathrm{MgSO}_{4}\right)$ and the solvent was evaporated under vacuum to give a yellow liquid. The residue was purified by column chromatography (eluent: cyclohexane/EtOAc, 100:0 to 90:10) to afford $\mathbf{2 6}$ (623 mg, 1.39 mmol, $58 \%$ yield) as a colorless liquid. IR (film) $v\left(\mathrm{~cm}^{-1}\right): 3379,2930,2094,1691,1601$, 1574, 1508, 1310, 1248, 1157, 1109, 1038. ${ }^{1} \mathrm{H}$ NMR (250 MHz, $\left.\mathrm{CDCl}_{3}\right): \delta 1.44$ (br s, 9H, $\mathrm{CH}_{3}+$ linker $\left.\mathrm{CH}_{2}\right), 1.63\left(\mathrm{~m}, 2 \mathrm{H}\right.$, linker $\left.\mathrm{CH}_{2}\right), 1.92\left(\mathrm{~m}, 1 \mathrm{H}\right.$, chromane-3- $\left.\mathrm{H}_{a} \mathrm{H}_{\mathrm{b}}\right), 2.10(\mathrm{~s}, 3 \mathrm{H}$, $\left.\mathrm{CH}_{3}\right), 2.12\left(\mathrm{~m}, 1 \mathrm{H}\right.$, chromane-3- $\left.\mathrm{H}_{\mathrm{a}} \mathrm{H}_{b}\right), 2.16\left(\mathrm{~s}, 3 \mathrm{H}, \mathrm{CH}_{3}\right), 2.20\left(\mathrm{~s}, 3 \mathrm{H}, \mathrm{CH}_{3}\right), 2.63(\mathrm{~m}, 4 \mathrm{H}$, chromane 4- $\mathrm{CH}_{2}+$ linker $\mathrm{CH}_{2}$ ), $3.28\left(\mathrm{t}, J=6.8 \mathrm{~Hz}, 2 \mathrm{H}, \mathrm{CH}_{2} \mathrm{~N}_{3}\right.$ ), 3.98, 4.08 (AB system, $J=$ $\left.9.3 \mathrm{~Hz}, 2 \mathrm{H}, \mathrm{OCH}_{2}\right), 7.03\left(\mathrm{~d}, J=8.6 \mathrm{~Hz}, 2 \mathrm{H}, \mathrm{H}_{\text {arom }}\right), 7.82\left(\mathrm{~d}, J=8.6 \mathrm{~Hz}, 2 \mathrm{H}, \mathrm{H}_{\text {arom }}\right), 9.89$ (s, $1 \mathrm{H}, \mathrm{CHO}) .{ }^{13} \mathrm{C}$ NMR $\left(62.9 \mathrm{MHz}, \mathrm{DMSO}-d_{6}\right): \delta 12.2\left(\mathrm{CH}_{3}\right), 15.1\left(\mathrm{CH}_{3}\right), 16.0\left(\mathrm{CH}_{3}\right), 20.7$ $\left(\mathrm{CH}_{2}\right), 22.9\left(\mathrm{CH}_{3}\right), 26.8\left(\mathrm{CH}_{2}\right), 28.8\left(\mathrm{CH}_{2}\right), 29.0\left(\mathrm{CH}_{2}\right), 29.8\left(\mathrm{CH}_{2}\right), 30.1\left(\mathrm{CH}_{2}\right), 30.2\left(\mathrm{CH}_{2}\right)$, 51.6 $\left(\mathrm{CH}_{2} \mathrm{~N}_{3}\right), 73.1,74.1,115.2\left(\mathrm{CH}_{\text {arom }}\right), 116.9,122.4,130.3,131.0,131.7,132.1\left(\mathrm{CH}_{\text {arom }}\right)$, 133.6, 149.1, 164.2, 190.9 (CHO). ESI-MS (pos. mode): $\mathrm{m} / z=472.25[\mathrm{M}+\mathrm{Na}]^{+}$. Anal. Calcd for $\mathrm{C}_{27} \mathrm{H}_{35} \mathrm{~N}_{3} \mathrm{O}_{3}$ (449.60): C, 72.13; H, 7.85; N, 9.35. Found: C, 72.50; H, 7.92; N, 9.09.

\subsubsection{8. (E)-3-(4-((6-(6-azidohexyl)-2,5,7,8-tetramethylchroman-2-yl)methoxy)benzylidene) pyrrolidine-2,5-dione (28)}

To a solution of $\mathbf{2 6}(0.52 \mathrm{mmol})$ in anhydrous $\mathrm{MeOH}(10 \mathrm{~mL})$ was added compound 2 (187 $\mathrm{mg}, 0.52 \mathrm{mmol}$ ) and the mixture was stirred under argon at room temperature for $12 \mathrm{~h}$. The suspension was filtered and washed with cooled $\mathrm{MeOH}$ to give $189 \mathrm{mg}(0.36 \mathrm{mmol}, 69 \%$ yield) of white powder. M.p. $130-132{ }^{\circ} \mathrm{C}$. IR (KBr) $v\left(\mathrm{~cm}^{-1}\right): 2927,2853,2085,1746,1699$, 1601, 1514, 1456, 1352, 1306, 1244, 1175, 1111. ${ }^{1} \mathrm{H}$ NMR $\left(400 \mathrm{MHz}, \mathrm{CDCl}_{3}\right): \delta 1.43(\mathrm{~s}, 3 \mathrm{H}$, $\mathrm{CH}_{3}$ ), 1.45 (br s, 6H, linker $\left.\mathrm{CH}_{2}\right), 1.63\left(\mathrm{~m}, 2 \mathrm{H}\right.$, linker $\left.\mathrm{CH}_{2}\right), 1.91\left(\mathrm{~m}, 1 \mathrm{H}\right.$, chromane-3- $\left.\mathrm{H}_{a} \mathrm{H}_{\mathrm{b}}\right)$, $2.10\left(\mathrm{~s}, 3 \mathrm{H}, \mathrm{CH}_{3}\right), 2.13\left(\mathrm{~m}, 1 \mathrm{H}\right.$, chromane $\left.3-\mathrm{H}_{\mathrm{a}} \mathrm{H}_{b}\right), 2.16\left(\mathrm{~s}, 3 \mathrm{H}, \mathrm{CH}_{3}\right), 2.21\left(\mathrm{~s}, 3 \mathrm{H}, \mathrm{CH}_{3}\right), 2.61$ (m, 2H, linker $\left.\mathrm{CH}_{2}\right), 2.67(\mathrm{~m}, 2 \mathrm{H}$, chromane 4-CH $), 3.28\left(\mathrm{t}, J=6.9 \mathrm{~Hz}, 2 \mathrm{H}, \mathrm{CH}_{2} \mathrm{~N}_{3}\right), 3.58(\mathrm{~d}$, $\left.J=2.2 \mathrm{~Hz}, 2 \mathrm{H}, \mathrm{CH}_{2} \mathrm{CO}\right), 3.95,4.05\left(\mathrm{AB}\right.$ system, $\left.J=9.3 \mathrm{~Hz}, 2 \mathrm{H}, \mathrm{OCH}_{2}\right), 7.00(\mathrm{~d}, J=8.9 \mathrm{~Hz}$, $\left.2 \mathrm{H}, \mathrm{H}_{\text {arom }}\right), 7.42$ (d, $\left.J=8.9 \mathrm{~Hz}, 2 \mathrm{H}, \mathrm{H}_{\text {arom }}\right), 7.56(\mathrm{~m}, 1 \mathrm{H}, \mathrm{CH}=\mathrm{C}), 8.38$ (br s, $\left.1 \mathrm{H}, \mathrm{NH}\right) .{ }^{13} \mathrm{C}$

NMR (100 MHz, $\left.\mathrm{CDCl}_{3}\right): \delta 12.2\left(\mathrm{CH}_{3}\right), 15.1\left(\mathrm{CH}_{3}\right), 16.0\left(\mathrm{CH}_{3}\right), 20.7\left(\mathrm{CH}_{2}\right), 22.9\left(\mathrm{CH}_{3}\right), 26.8$ $\left(\mathrm{CH}_{2}\right), 28.8\left(\mathrm{CH}_{2}\right), 29.0\left(\mathrm{CH}_{2}\right), 29.8\left(\mathrm{CH}_{2}\right), 30.1\left(\mathrm{CH}_{2}\right), 30.2\left(\mathrm{CH}_{2}\right), 35.3\left(\mathrm{CH}_{2}\right), 51.6$ $\left(\mathrm{CH}_{2} \mathrm{~N}_{3}\right), 73.0,74.2,115.6\left(\mathrm{CH}_{\text {arom }}\right), 116.9,121.4,122.4,126.8,130.9,131.7,132.2\left(\mathrm{CH}_{\text {arom }}\right)$, 133.5, $135.0(\mathrm{CH}=\mathrm{C}), 149.1,161.0,171.3(\mathrm{C}=\mathrm{O}), 174.2(\mathrm{C}=\mathrm{O})$. ESI-MS (pos. mode): $\mathrm{m} / \mathrm{z}=$ $531.29[\mathrm{M}+\mathrm{H}]^{+}, 553.28[\mathrm{M}+\mathrm{Na}]^{+}$. Anal. Calcd for $\mathrm{C}_{31} \mathrm{H}_{38} \mathrm{~N}_{4} \mathrm{O}_{4}(530.67): \mathrm{C}, 70.16 ; \mathrm{H}, 7.22 ; \mathrm{N}$, 10.56. Found: C, 70.50; H, 7.22; N, 10.20. 


\subsubsection{9. (2R,3R,4S,5R,6R)-2-(acetoxymethyl)-6-(prop-2-yn-1-yloxy)tetrahydro-2H-pyran-}

\section{3,4,5-triyl triacetate (29)}

Acetylation of $\alpha$-D-glucose: procedure reported by Wolfrom and Thompson [23] was adapted as follows: to a suspension of $\alpha$-D-glucose $(3.00 \mathrm{~g}, 16.65 \mathrm{mmol})$ in acetic anhydride $(20.46$ $\mathrm{mL}, 216.47 \mathrm{mmol})$ was added sodium acetate $(1.50 \mathrm{~g}, 18.32 \mathrm{mmol})$ under argon. The mixture was refluxed during $2 \mathrm{~h}$ and cooled to room temperature before being cooled in an ice bath. Water $(50 \mathrm{~mL})$ was added and the suspension was filtered, washed with water $(3 \times 20 \mathrm{~mL})$, and carefully dried to give $3.618 \mathrm{~g}(9.27 \mathrm{mmol}, 56 \%$ yield $)$ of white powder which was used in the next step without further purification.

Propargylation at the 1-position: this step was realized according to the work of Murray et al. [24]. Spectral data of the compound agreed with the reported data.

\subsubsection{0. $(2 R, 3 R, 4 S, 5 R, 6 R)-2-($ acetoxymethyl)-6-((1-(6-(2-)(4-((E)-(2,5-dioxopyrrolidin-3-} ylidene)methyl)phenoxy)methyl)-2,5,7,8-tetramethylchroman-6-yl)hexyl)-1H-1,2,3-triazol-4yl)methoxy)tetrahydro-2H-pyran-3,4,5-triyl triacetate (30)

To a mixture of 28 (138 mg, $0.26 \mathrm{mmol})$ and $29(100 \mathrm{mg}, 0.26 \mathrm{mmol})$ were added $t$ - $\mathrm{BuOH}$ $(20 \mathrm{~mL})$ and $\mathrm{MeOH}(2 \mathrm{~mL})$ and sonication was applied. To the resulting solution was added a mixture of $\mathrm{CuSO}_{4}(58 \mathrm{mg}, 0.36 \mathrm{mmol})$ and sodium ascorbate $(71 \mathrm{mg}, 0.36 \mathrm{mmol})$ in water $(0.5 \mathrm{~mL})$. The reaction mixture was stirred under argon at room temperature for $12 \mathrm{~h}$, and the solvents were evaporated. The residue was dissolved in EtOAc $(30 \mathrm{~mL})$ and the solution was washed with water $(3 \times 20 \mathrm{~mL})$, dried $\left(\mathrm{MgSO}_{4}\right)$ and concentrated under vacuum to give a yellow residue which was purified by column chromatography (eluent: cyclohexane/EtOAc, 100:0 to 20:80) to afford $171 \mathrm{mg}(0.19 \mathrm{mmol}, 74 \%$ yield $)$ of white powder. M.p. $88-90{ }^{\circ} \mathrm{C}$. IR (ATR): $v\left(\mathrm{~cm}^{-1}\right)$ 2928, 2853, 1748, 1713, 1601, 1510, 1217, 1034. ${ }^{1} \mathrm{H}$ NMR (400 MHz, $\left.\mathrm{CDCl}_{3}\right): \delta 1.42\left(\mathrm{~m}, 9 \mathrm{H}\right.$, chromane $\mathrm{CH}_{3}+$ linker $\left.\mathrm{CH}_{2}\right), 1.91(\mathrm{~m}, 3 \mathrm{H}$, chromane $3-\mathrm{HaHb}+$ triazole- $\left.\mathrm{CH}_{2}-\mathrm{CH}_{2}\right), 1.98\left(\mathrm{~s}, 3 \mathrm{H}, \mathrm{COCH}_{3}\right), 2.00\left(\mathrm{~s}, 3 \mathrm{H}, \mathrm{COCH}_{3}\right), 2.03\left(\mathrm{~s}, 3 \mathrm{H}, \mathrm{COCH}_{3}\right), 2.09$ (s, $6 \mathrm{H}, \mathrm{COCH}_{3}+$ chromane $\left.\mathrm{CH}_{3}\right), 2.12\left(\mathrm{~m}, 1 \mathrm{H}\right.$, chromane 3-HaHb), $2.14\left(\mathrm{~s}, 3 \mathrm{H}\right.$, chromane $\left.\mathrm{CH}_{3}\right)$, 2.19 (s, 3H, chromane $\left.\mathrm{CH}_{3}\right), 2.59\left(\mathrm{~m}, 2 \mathrm{H}\right.$, linker $\left.\mathrm{CH}_{2}\right), 2.66(\mathrm{~m}, 2 \mathrm{H}$, chromane 4-H), 3.59 (d, $J=2.3 \mathrm{~Hz}, 2 \mathrm{H}, \mathrm{CH}_{2} \mathrm{CO}$ ), 3.74 (X part of an ABX system, $1 \mathrm{H}$, glucose 5-H), 3.95, 4.04 (AB system, $J=9.3 \mathrm{~Hz}, 2 \mathrm{H}, \mathrm{OCH}_{2}$ ), 4.15, 4.27 (AB part of an ABX system, $J=12.3,4.7,2.1 \mathrm{~Hz}$, $2 \mathrm{H}$, glucose 6-H + 6'-H), 4.35 (br t $, J=7.1 \mathrm{~Hz}, 2 \mathrm{H}$, linker triazole- $\left.\mathrm{CH}_{2}\right), 4.69$ (d, $J=8.0 \mathrm{~Hz}$, $1 \mathrm{H}$, glucose 1-H), 4.84, 4.95 (AB system, $\left.J=12.6 \mathrm{~Hz}, 2 \mathrm{H}, \mathrm{OCH}_{2}\right), 5.01(\mathrm{dd}, J=9.5,8.0 \mathrm{~Hz}$, $1 \mathrm{H}$, glucose 2-H), $5.10(\mathrm{t}, J=9.6 \mathrm{~Hz}, 1 \mathrm{H}$, glucose $4-\mathrm{H}), 5.20(\mathrm{t}, J=9.5 \mathrm{~Hz}, 1 \mathrm{H}$, glucose $3-\mathrm{H})$, $6.99\left(\mathrm{~d}, J=8.9 \mathrm{~Hz}, 2 \mathrm{H}, \mathrm{H}_{\text {arom }}\right), 7.42\left(\mathrm{~d}, J=8.9 \mathrm{~Hz}, 2 \mathrm{H}, \mathrm{H}_{\text {arom }}\right), 7.50$ (br s, $1 \mathrm{H}$, triazole $\left.\mathrm{H}\right)$, $7.55(\mathrm{t}, J=2.2 \mathrm{~Hz}, 1 \mathrm{H}, \mathrm{C}=\mathrm{CH}), 7.88(\mathrm{~s}, 1 \mathrm{H}, \mathrm{NH}) .{ }^{13} \mathrm{C} \mathrm{NMR}\left(100 \mathrm{MHz}, \mathrm{CDCl}_{3}\right): \delta 12.2$ $\left(\mathrm{CH}_{3}\right), 15.1\left(\mathrm{CH}_{3}\right), 16.0\left(\mathrm{CH}_{3}\right), 20.7\left(2 \times \mathrm{COCH}_{3}\right), 20.8\left(\mathrm{COCH}_{3}\right), 20.9\left(\mathrm{COCH}_{3}\right), 22.9\left(\mathrm{CH}_{3}\right)$, $26.6\left(\mathrm{CH}_{2}\right), 28.8\left(\mathrm{CH}_{2}\right), 29.6\left(\mathrm{CH}_{2}\right), 30.0\left(\mathrm{CH}_{2}\right), 30.1\left(\mathrm{CH}_{2}\right), 30.5\left(\mathrm{CH}_{2}\right), 35.3\left(\mathrm{CH}_{2}\right), 50.7$ $\left(\mathrm{CH}_{2} \mathrm{~N}\right), 62.0,63.2,68.5$ (glucose $\left.\mathrm{CH}\right), 71.4$ (glucose $\left.\mathrm{CH}\right), 72.0$ (glucose $\left.\mathrm{CH}\right), 72.9$ (glucose $\mathrm{CH}$ ), 73.0, 74.2, 100.2 (glucose 1-CH), 115.6 (phenyl $\mathrm{CH}$ ) 116.9, 121.4, 122.4, 122.8 (triazole $\mathrm{CH}), 126.9,130.8,131.7,132.2$ (phenyl $\mathrm{CH}), 133.5,135.0(\mathrm{CH}=\mathrm{C}), 144.2,149.1,161.0$, $169.5(\mathrm{C}=\mathrm{O}), 169.6(\mathrm{C}=\mathrm{O}), 170.4(\mathrm{C}=\mathrm{O}), 170.8(\mathrm{C}=\mathrm{O}), 171.0(\mathrm{C}=\mathrm{O}), 174.0(\mathrm{C}=\mathrm{O})$. ESI-MS (pos. mode): $m / z=917.41[\mathrm{M}+\mathrm{H}]^{+}, 939.40[\mathrm{M}+\mathrm{Na}]^{+}, 955.37[\mathrm{M}+\mathrm{K}]^{+}$. Anal. Calcd for $\mathrm{C}_{48} \mathrm{H}_{60} \mathrm{~N}_{4} \mathrm{O}_{14}$ (917.01): C, 62.87; H, 6.59; N, 6.11. Found: C, 62.39; H, 6.68; N, 6.05. 


\subsubsection{3-((E)-4-((2,5,7,8-tetramethyl-6-(6-(4-)(((2R,3R,4S,5S,6R)-3,4,5-trihydroxy-6-}

(hydroxymethyl)tetrahydro-2H-pyran-2-yl)oxy)methyl)-1H-1,2,3-triazol-1-yl)hexyl)chroman2-yl)methoxy)benzylidene)pyrrolidine-2,5-dione (31)

A suspension of compound $30(87 \mathrm{mg}, 0.09 \mathrm{mmol})$ in anhydrous $\mathrm{MeOH}(5 \mathrm{~mL})$ was sonicated until dissolution. A solution of $\mathrm{MeONa}$ in $\mathrm{MeOH}(2.09 \mathrm{~mL}, 1.15 \mathrm{mg} / \mathrm{mL})$ was added at room temperature and stirred under argon for $1 \mathrm{~h}$. Amberlite ${ }^{\circledR}$ IR $120 \mathrm{H}$ was added until neutral $\mathrm{pH}$ and the suspension was filtered to give after evaporation of the filtrate an orange liquid which was purified by reverse-phase column chromatography (eluent: $\mathrm{H}_{2} \mathrm{O}$ (0.1\% TFA)/MeOH, 90:10 to 10:90) to afford after lyophilisation $71 \mathrm{mg}(0.09 \mathrm{mmol}, 100 \%$ yield) of white powder. M.p. 126-128 ${ }^{\circ} \mathrm{C}$. IR (ATR): $v\left(\mathrm{~cm}^{-1}\right) 3387,2914,2855,1717,1684$, 1600, 1340, 1306, 1250, 1165, 1076, 1043, 525. ${ }^{1} \mathrm{H}$ NMR (400 MHz, DMSO- $\left.d_{6}\right)$ : $\delta 1.31$ (m, $7 \mathrm{H}$, chromane $\mathrm{CH}_{3}+$ linker $\left.\mathrm{CH}_{2}\right), 1.39\left(\mathrm{~m}, 2 \mathrm{H}\right.$, linker $\left.\mathrm{CH}_{2}\right), 1.82\left(\mathrm{~m}, 3 \mathrm{H}\right.$, chromane $3-\mathrm{H}_{a} \mathrm{H}_{\mathrm{b}}+$ triazole- $\left.\mathrm{CH}_{2} \mathrm{CH}_{2}\right), 1.97\left(\mathrm{~s}, 3 \mathrm{H}\right.$, chromane $\left.\mathrm{CH}_{3}\right), 2.00\left(\mathrm{~m}, 1 \mathrm{H}\right.$, chromane $\left.3-\mathrm{H}_{\mathrm{a}} \mathrm{H}_{b}\right), 2.08(\mathrm{~s}, 6 \mathrm{H}$, chromane $\left.\mathrm{CH}_{3}\right), 2.50\left(2 \mathrm{H}\right.$, linker $\left.\mathrm{CH}_{2}\right), 2.61(\mathrm{~m}, 2 \mathrm{H}$, chromane 4-H), $2.97(\mathrm{t}, J=8.7 \mathrm{~Hz}, 1 \mathrm{H}$, glucose 2-H), 3.01-3.17 (m, 3H, glucose $3-\mathrm{H}+4-\mathrm{H}+5-\mathrm{H}), 3.45,3.70$ (AB part of an ABX system, $J=11.8,6.2,1.6 \mathrm{~Hz}, 2 \mathrm{H}$, glucose $\left.6-\mathrm{H}+6^{\prime}-\mathrm{H}\right), 3.59\left(\mathrm{~d}, J=2.1 \mathrm{~Hz}, 2 \mathrm{H}, \mathrm{CH}_{2} \mathrm{CO}\right)$, 4.03, 4.08 (AB system, $J=10.1 \mathrm{~Hz}, 2 \mathrm{H}, \mathrm{OCH}_{2}$ ), 4.14 (br s, 4H, 4 x OH), 4.25 (d, $J=7.8 \mathrm{~Hz}$, $1 \mathrm{H}$, glucose 1-H), $4.34\left(\mathrm{t}, J=7.0 \mathrm{~Hz}, 2 \mathrm{H}\right.$, linker triazole- $\left.\mathrm{CH}_{2}\right), 4.62,4.83$ (AB system, $J=$ $\left.12.2 \mathrm{~Hz}, 2 \mathrm{H}, \mathrm{OCH}_{2}\right), 7.06\left(\mathrm{~d}, J=8.8 \mathrm{~Hz}, 2 \mathrm{H}, \mathrm{H}_{\text {arom }}\right), 7.33(\mathrm{~s}, 1 \mathrm{H}, \mathrm{C}=\mathrm{CH}), 7.55(\mathrm{~d}, J=8.8 \mathrm{~Hz}$, $\left.2 \mathrm{H}, \mathrm{H}_{\text {arom }}\right), 8.11(\mathrm{~s}, 1 \mathrm{H}$, triazole $\mathrm{H}), 11.34(\mathrm{~s}, 1 \mathrm{H}, \mathrm{NH}) .{ }^{13} \mathrm{C}$ NMR $\left(100 \mathrm{MHz}, \mathrm{DMSO}-d_{6}\right): \delta$ $11.9\left(\mathrm{CH}_{3}\right), 14.6\left(\mathrm{CH}_{3}\right), 15.5\left(\mathrm{CH}_{3}\right), 20.0\left(\mathrm{CH}_{2}\right), 21.6\left(\mathrm{CH}_{3}\right), 25.8\left(\mathrm{CH}_{2}\right), 28.1\left(\mathrm{CH}_{2}\right), 28.9$ $\left(\mathrm{CH}_{2}\right), 29.3\left(\mathrm{CH}_{2}\right), 29.5\left(\mathrm{CH}_{2}\right), 29.8\left(\mathrm{CH}_{2}\right), 34.8\left(\mathrm{CH}_{2} \mathrm{CO}\right) 49.3\left(\mathrm{CH}_{2} \mathrm{~N}\right.$ triazole $), 61.1$ $\left(\mathrm{CH}_{2} \mathrm{OH}\right), 61.6\left(\mathrm{OCH}_{2}\right.$ triazole $), 70.1($ glucose $\mathrm{CH}), 72.6\left(\mathrm{OCH}_{2}\right), 73.4$ (glucose $\left.\mathrm{CH}\right), 73.9$ $\left(\mathrm{OC}_{\text {quat }}\right.$ ), 76.7 (glucose $\mathrm{CH}$ ), 77.0 (glucose $\left.\mathrm{CH}\right), 102.1$ (glucose 1-CH), 115.3 (phenyl CH), 116.6, 120.9, 124.1 (triazole $\mathrm{CH}), 124.1,127.0,130.0,131.0,131.4(\mathrm{CH}=\mathrm{C}), 132.0$ (phenyl $\mathrm{CH}), 132.5,143.7,148.5,160.0,172.1(\mathrm{C}=\mathrm{O}), 175.8(\mathrm{C}=\mathrm{O})$. ESI-MS (pos. mode): $\mathrm{m} / \mathrm{z}=$ $771.36[\mathrm{M}+\mathrm{Na}]^{+}$. Anal. Calcd for $\mathrm{C}_{40} \mathrm{H}_{52} \mathrm{~N}_{4} \mathrm{O}_{10}, 2 \mathrm{H}_{2} \mathrm{O}$ (784.39): C, 61.21; H, 7.19; N, 7.14. Found: C, 61.01; H, 7.32; N, 6.95.

\subsection{Biological evaluation on cancerous cell lines}

\subsubsection{Cell Lines and Reagents}

MCF-7, MDA-MB-231, MDA-MB-453 and Hs578T human breast cancer cell lines, HCT116 colon cancer cell line, and U87 glioblastoma cell line were obtained from American Type Culture Collection (Manassas, VA, USA). These cell lines were grown at $37{ }^{\circ} \mathrm{C}$ under $5 \%$ $\mathrm{CO}_{2}$ in Dulbecco's Modified Eagle Medium (DMEM, Gibco ${ }^{\circledR}$, Thermo Fisher Scientific, Villebon-sur-Yvette, France) for MCF-7, Hs578T, U87, and HCT116, and Roswell Park Memorial Institute (RPMI) 1640 medium $\left(\right.$ Gibco $\left.^{\circledR}\right)$ for MDA-MB-231 and MDA-MB-453. These phenol red containing media were supplemented with $2 \mathrm{mM}$ L-glutamine (SigmaAldrich, Saint-Quentin Fallavier, France) and 10\% fetal calf serum (FCS, Sigma-Aldrich). In addition, the medium was supplemented with $10 \mu \mathrm{g} / \mathrm{mL}$ insulin for Hs578T cell line. For U87 cells, the medium was supplemented with $1.25 \mathrm{mM}$ sodium pyruvate, $50 \mu \mathrm{M}$ non-essential amino acid, $10.8 \mu \mathrm{g} / \mathrm{mL}$ L-serine, $20 \mu \mathrm{g} / \mathrm{mL}$ L-asparagine, $0.4 \%$ vitamins (100X stock 
solution) and $1 \%$ essential amino acids (50X stock solution) (Thermo Fisher Scientific). Compounds to be tested were dissolved in Dimethyl sulfoxide (DMSO, Sigma-Aldrich).

\subsubsection{Cell Treatments}

The different cell lines were seeded at the appropriate density in their respective medium supplemented with $10 \%$ FCS and incubated for $24 \mathrm{~h}$ to allow for cell attachment. For crystal violet staining, cells were seeded in 96-well plates at a density of $1.5 \times 10^{4}$ cells/well (MDAMB-231, MCF-7, Hs578T, and U87 cells) or $1.2 \times 10^{4}$ cells/well (HCT116) or $2 \times 10^{4}$ cells/well (MDA-MB-453 cells). For flow cytometry analyses, MDA-MB-231 cells were seeded in $60 \mathrm{~mm}$-diameter culture dishes at $9 \times 10^{5}$ cells/dish. The cells were then treated in their respective medium for 48 or 72 hours with the considered compounds at the indicated concentrations. Control cells were treated with DMSO $0.090 \%$ or $0.012 \%$ to compare with cells exposed with $45 \mu \mathrm{M}$ TGZ or $6 \mu \mathrm{M}$ compound 10, respectively.

\subsubsection{Crystal Violet Staining Assay}

At the end of the treatment, cells were washed with phosphate-buffered saline (PBS). Cells were then fixed and stained for 20 min with $0.2 \%$ crystal violet (Sigma-Aldrich) in $2 \%$ ethanol. This staining solution was filtered prior to use with a syringe-driven filter unit $(0.2$ $\mu \mathrm{m}$ pore size, VWR international, Radnor, PA, USA) to eliminate dye precipitates. Cells were then washed with distilled water to remove excess dye. The plates were dried and the dye was dissolved in $10 \%$ acetic acid. Cell number was determined by absorbance at $595 \mathrm{~nm}$ with a VICTOR $^{\text {TM }}$ X3 multilabel plate reader (PerkinElmer, Courtaboeuf, France). In each condition, the concentration leading to a decrease of $50 \%$ of the cell number $\left(\mathrm{IC}_{50}\right)$ was determined.

\subsubsection{Cell Cycle Analysis}

At the end of the treatment, culture medium containing the non-adherent cells was collected. Adherent cells were washed with PBS, trypsined (0.05\% trypsin-EDTA in PBS buffer, Gibco $^{\circledR}$ ) and resuspended in a medium containing $10 \%$ FCS. Non-adherent cells and trypsined cells were pooled and counted. 1 × $10^{6}$ cells were centrifuged at $500 \mathrm{~g}$ for $5 \mathrm{~min}$ at room temperature and the pellet was rinsed with PBS. Cells were then resuspended in $600 \mu \mathrm{L}$ of PBS and $1,400 \mu \mathrm{L}$ of cold $100 \%$ ethanol were added drop by drop while vortexing the suspension to permeabilize and fix the cells efficiently. $5 \times 10^{5}$ cells were then centrifugated at $800 \mathrm{~g}$ for $10 \mathrm{~min}$ at room temperature. The pellet was resuspended in $500 \mu \mathrm{L}$ of DNA staining solution containing $200 \mu \mathrm{g}$ of RNAse A (Invitrogen, Thermo Fisher Scientific) and 2 $\mu \mathrm{g}$ of propidium iodide (PI) (Thermo Fisher Scientific). Samples were incubated for $15 \mathrm{~min}$ in the dark at room temperature. Finally, cellular DNA content was determined with a BD FACSCalibur $^{\mathrm{TM}}$ flow cytometer (BD Biosciences) using CellQuest ${ }^{\mathrm{TM}}$ Pro software (BD Biosciences). 20,000 events were analyzed and the percentage of cells in each phase of the cell cycle was determined. 


\subsubsection{Annexin V/propidium iodide (PI) apoptosis assay}

At the end of the treatment, culture medium containing the non-adherent cells was collected. Adherent cells were washed with PBS, trypsined (0.05\% trypsin-EDTA in PBS buffer, Gibco $^{\circledR}$ ) and resuspended in a medium containing $10 \%$ FCS. Non-adherent cells and trypsined cells were pooled and centrifuged at $200 \mathrm{~g}$ for $10 \mathrm{~min}$ at room temperature and the pellet was rinsed with PBS. $1 \times 10^{6}$ cells were centrifuged at $200 \mathrm{~g}$ for $10 \mathrm{~min}$ at room temperature and then added to a binding buffer solution (0.1 M HEPES pH 7.4, $1.4 \mathrm{M} \mathrm{NaCl}, 25 \mathrm{mM} \mathrm{CaCl}$, $\mathrm{pH}$ 7.4) to facilitate Annexin V binding to phosphatidylserine. $2 \mu \mathrm{g}$ of PI (Thermo Fisher Scientific) and $2.5 \mu \mathrm{L}$ of FITC Annexin V (BD Biosciences) were added to the cell suspension and incubated for $15 \mathrm{~min}$ in the dark at room temperature. Action of Annexin $\mathrm{V}$ was inhibited by addition of binding buffer solution. 10,000 events were analyzed and the percentage of Annexin V and/or PI positive cells was determined with a BD FACSCalibur ${ }^{\mathrm{TM}}$ flow cytometer (BD Biosciences) using CellQuest ${ }^{\mathrm{TM}}$ Pro software (BD Biosciences).

\subsubsection{Statistical Analysis}

The results of cell cycle analysis and Annexin V/PI apoptosis assay were analyzed using a two-tailed unpaired t test with Welch's correction. Differences in which P-value was less than 0.05 were statistically significant.

\subsection{Biological evaluation on non tumoral hepatocytes}

\subsubsection{Cell culture}

The human liver resection was collected in accordance with Article L.1211-2 of the French Public Health Code, amended by Law No. 2004-800 of August 6, 2004. Human hepatocytes were isolated from macroscopically healthy surgical liver waste after tumor resection by a two-step collagenase perfusion. Single donor (58 years old Caucasian female)-derived hepatocytes were seeded onto collagen-coated 96 -well plates $\left(7 \times 10^{4}\right.$ cells/well $)$ in DMEM medium supplemented with FCS $(10 \%)$, insulin $(4 \mu \mathrm{g} / \mathrm{ml})$, dexamethasone $(1 \mu \mathrm{M})$ and gentamycin $(50 \mu \mathrm{g} / \mathrm{ml})$. Cells were incubated overnight at $37^{\circ} \mathrm{C}$ under a humidified $5 \%$ $\mathrm{CO}_{2} / 95 \%$ air atmosphere.

\subsubsection{Cell treatment}

The medium was replaced by a serum-free medium, consisted of DMEM supplemented with insulin $(4 \mu \mathrm{g} / \mathrm{ml})$, dexamethasone $(1 \mu \mathrm{M})$ and gentamycin $(50 \mu \mathrm{g} / \mathrm{ml})$. The cultures were exposed to increasing doses of compound $\mathbf{1 0}$ at 9 concentrations ranging from 0 to $200 \mu \mathrm{M}$. After $24 \mathrm{~h}$ of treatment, hepatocytes were incubated with MTT $(0.5 \mathrm{mg} / \mathrm{ml})$ for $2 \mathrm{~h}$ at $37^{\circ} \mathrm{C}$. The formazan crystals were then dissolved in DMSO and the absorbance was measured at 570 nm. 


\section{Acknowledgments}

The authors thank Fabien Lachaud and François Dupire for spectroscopic measurements, Sandrine Adach for elemental analysis, MENRT for a fellowship to Dorian Dupommier and Claire Muller. The authors are grateful to Alicia Chateau and Muriel Barberi-Heyob for having provided the U87 cell line. Technical help from Jessica Camera, Marianna Saribekyan, and Marie Zaffino is also gratefully acknowledged.

\section{Appendix A. Supplementary data}

Supplementary data associated with this article can be found in the online version, at http://dx.doi.org/xxxxx. These data include ${ }^{1} \mathrm{H}$ and ${ }^{13} \mathrm{C}$ NMR spectra of tested compounds, and synthetic protocols in the frame of the attempts to prepare derivatives suitable for X-ray analysis (preparation of compounds 22-26). Representative dose-dependent responses of MDA-MB-231 cells to TGZ and compound $\mathbf{1 0}$ were also included. Representative dosedependent responses of U87 and HCT116 cells to compound $\mathbf{1 0}$ were also inserted.

\section{References}

[1] F. Bray, J. Ferlay, I. Soerjomataram, R.L. Siegel, L.A. Torre, A. Jemal, Global cancer statistics 2018: GLOBOCAN estimates of incidence and mortality worldwide for 36 cancers in 185 countries, CA: A Cancer Journal for Clinicians. 68 (2018) 394-424. https://doi.org/10.3322/caac.21492.

[2] K.L. Maughan, M.A. Lutterbie, P. Ham, Treatment of Breast Cancer, AFP. 81 (2010) 1339-1346.

[3] E.A. Musgrove, R.L. Sutherland, Biological determinants of endocrine resistance in breast cancer, Nature Reviews Cancer. 9 (2009) 631-643. https://doi.org/10.1038/nrc2713.

[4] F.X. Claret, T.T. Vu, Trastuzumab: Updated Mechanisms of Action and Resistance in Breast Cancer, Front. Oncol. 2 (2012). https://doi.org/10.3389/fonc.2012.00062.

[5] K.G. Chen, B.I. Sikic, Molecular Pathways: Regulation and Therapeutic Implications of Multidrug Resistance, Clin Cancer Res. 18 (2012) 1863-1869. https://doi.org/10.1158/10780432.CCR-11-1590.

[6] C. Yam, S.A. Mani, S.L. Moulder, Targeting the Molecular Subtypes of Triple Negative Breast Cancer: Understanding the Diversity to Progress the Field, The Oncologist. 22 (2017) 1086-1093. https://doi.org/10.1634/theoncologist.2017-0095.

[7] Mohd.J. Naim, Md.J. Alam, S. Ahmad, F. Nawaz, N. Shrivastava, M. Sahu, O. Alam, Therapeutic journey of 2,4-thiazolidinediones as a versatile scaffold: An insight into structure activity relationship, European Journal of Medicinal Chemistry. 129 (2017) 218-250. https://doi.org/10.1016/j.ejmech.2017.02.031.

[8] Sucheta, S. Tahlan, P.K. Verma, Biological potential of thiazolidinedione derivatives of synthetic origin, Chemistry Central Journal. 11 (2017) 130. https://doi.org/10.1186/s13065-017-0357-2.

[9] N. Chadha, M.S. Bahia, M. Kaur, O. Silakari, Thiazolidine-2,4-dione derivatives: Programmed chemical weapons for key protein targets of various pathological conditions, Bioorganic \& Medicinal Chemistry. 23 (2015) 2953-2974. https://doi.org/10.1016/j.bmc.2015.03.071.

[10]S. Prost, F. Relouzat, M. Spentchian, Y. Ouzegdouh, J. Saliba, G. Massonnet, J.-P. Beressi, E. Verhoeyen, V. Raggueneau, B. Maneglier, S. Castaigne, C. Chomienne, S. Chrétien, P. Rousselot, P. Leboulch, Erosion of the chronic myeloid leukaemia stem cell pool by PPAR $\gamma$ agonists, Nature. 525 (2015) 380-383. https://doi.org/10.1038/nature15248. 
[11]V. Shafiei $\square$ Irannejad, N. Samadi, R. Salehi, B. Yousefi, N. Zarghami, New insights into antidiabetic drugs: Possible applications in cancer treatment, Chemical Biology \& Drug Design. 90 (2017) 1056-1066. https://doi.org/10.1111/cbdd.13013.

[12]S. Salamone, C. Colin, I. Grillier-Vuissoz, S. Kuntz, S. Mazerbourg, S. Flament, H. Martin, L. Richert, Y. Chapleur, M. Boisbrun, Synthesis of new troglitazone derivatives: Anti-proliferative activity in breast cancer cell lines and preliminary toxicological study, European Journal of Medicinal Chemistry. 51 (2012) 206-215. https://doi.org/10.1016/j.ejmech.2012.02.044.

[13] A. Bordessa, C. Colin-Cassin, I. Grillier-Vuissoz, S. Kuntz, S. Mazerbourg, G. Husson, M. Vo, S. Flament, H. Martin, Y. Chapleur, M. Boisbrun, Optimization of troglitazone derivatives as potent anti-proliferative agents: Towards more active and less toxic compounds, European Journal of Medicinal Chemistry. 83 (2014) 129-140. https://doi.org/10.1016/j.ejmech.2014.06.015.

[14]S. Mazerbourg, S. Kuntz, I. Grillier-Vuissoz, A. Berthe, M. Geoffroy, S. Flament, A. Bordessa, M. Boisbrun, Reprofiling of troglitazone towards more active and less toxic derivatives: a new hope for cancer treatment?, Current Topics in Medicinal Chemistry. 16 (2016) 2115-2124.

[15]S. Saha, L.S. New, H.K. Ho, W.K. Chui, E.C.Y. Chan, Investigation of the role of the thiazolidinedione ring of troglitazone in inducing hepatotoxicity, Toxicology Letters. 192 (2010) 141-149. https://doi.org/10.1016/j.toxlet.2009.10.014.

[16]S. Saha, D.S.Z. Chan, C.Y. Lee, W. Wong, L.S. New, W.K. Chui, C.W. Yap, E.C.Y. Chan, H.K. Ho, Pyrrolidinediones reduce the toxicity of thiazolidinediones and modify their anti-diabetic and anti-cancer properties, European Journal of Pharmacology. 697 (2012) 13-23. https://doi.org/10.1016/j.ejphar.2012.09.021.

[17]E.A. Couladouros, V.I. Moutsos, M. Lampropoulou, J.L. Little, J.A. Hyatt, A Short and Convenient Chemical Route to Optically Pure 2-Methyl Chromanmethanols. Total Asymmetric Synthesis of $\beta-, \gamma-$, and $\delta$-Tocotrienols, J. Org. Chem. 72 (2007) 6735-6741. https://doi.org/10.1021/jo0705418.

[18]G. Machek, H. Haas, Zur Kenntnis der Dioxydiphenylsulfone, Journal Für Praktische Chemie. 160 (1942) 41-64. https://doi.org/10.1002/prac.19421600105.

[19]J.A. Hyatt, C. Skelton, A kinetic resolution route to the (S)-chromanmethanol intermediate for synthesis of the natural tocols, Tetrahedron: Asymmetry. 8 (1997) 523-526. https://doi.org/10.1016/S0957-4166(97)00020-7.

$[20]$ R.V. Shafikov, A.Yu. Spivak, V.N. Odinokov, Enantioselective transesterification of ( \pm )-6benzyloxy-2,5,7,8-tetramethyl-3,4-dihydro-2H-1-benzopyran-2-ylmethanol catalyzed by the Amano PS lipase in the ionic liquid [bmim]PF6, Russ Chem Bull. 59 (2010) 2129-2132. https://doi.org/10.1007/s11172-010-0367-x.

[21]P.M. Holstein, J.J. Holstein, E.C. Escudero-Adán, O. Baudoin, A.M. Echavarren, Ferrocene derivatives of liquid chiral molecules allow assignment of absolute configuration by X-ray crystallography, Tetrahedron: Asymmetry. 28 (2017) 1321-1329.

https://doi.org/10.1016/j.tetasy.2017.09.002.

[22]S. Salamone, M. Boisbrun, C. Didierjean, Y. Chapleur, From D-glucuronic acid to L-iduronic acid derivatives via a radical tandem decarboxylation-cyclization, Carbohydrate Research. 386 (2014) 99-105. https://doi.org/10.1016/j.carres.2014.01.006.

[23]M.L. Wolfrom, A. Thompson, Acetylation, in: Reactions of Carbohydrates, Academic Press, New York - London, 1963: pp. 211-215.

[24]A.B. Murray, M. Quadri, H. Li, R. McKenna, N.A. Horenstein, Synthesis of saccharinglycoconjugates targeting carbonic anhydrase using a one-pot cyclization/deprotection strategy, Carbohydrate Research. 476 (2019) 65-70. https://doi.org/10.1016/j.carres.2019.03.001.

[25]S.H. Burri, V. Gondi, P.D. Brown, M.P. Mehta, The Evolving Role of Tumor Treating Fields in Managing Glioblastoma: Guide for Oncologists., Am J Clin Oncol. 41 (2018) 191-196. https://doi.org/10.1097/COC.0000000000000395.

[26]J.S. Burns, G. Manda, Metabolic Pathways of the Warburg Effect in Health and Disease: Perspectives of Choice, Chain or Chance, International Journal of Molecular Sciences. 18 (2017) 2755. https://doi.org/10.3390/ijms18122755.

[27]S.-Y. Kim, Cancer Energy Metabolism: Shutting Power off Cancer Factory, Biomolecules \& Therapeutics. 26 (2018) 39-44. https://doi.org/10.4062/biomolther.2017.184. 
[28]E.C. Calvaresi, P.J. Hergenrother, Glucose conjugation for the specific targeting and treatment of cancer, Chemical Science. 4 (2013) 2319. https://doi.org/10.1039/c3sc22205e.

[29]A. Berthe, S. Flament, S. Grandemange, M. Zaffino, M. Boisbrun, S. Mazerbourg, $\Delta 2-$

Troglitazone promotes cytostatic rather than pro-apoptotic effects in breast cancer cells cultured in high serum conditions, Cell Cycle. 15 (2016) 3402-3412. https://doi.org/10.1080/15384101.2016.1245248.

[30]H.E. Gottlieb, V. Kotlyar, A. Nudelman, NMR Chemical Shifts of Common Laboratory Solvents as Trace Impurities, J. Org. Chem. 62 (1997) 7512-7515. https://doi.org/10.1021/jo971176v. 
New desulfured troglitazone derivatives were prepared with improved chemical synthesis and a deracemization strategy

Their pro-apoptotic activity was evaluated against breast cancer cell lines

Further biological studies revealed that the lead compound is a powerful pro-apoptotic agent 


\section{Declaration of interests}

$\bigotimes$ The authors declare that they have no known competing financial interests or personal relationships that could have appeared to influence the work reported in this paper.

$\square$ The authors declare the following financial interests/personal relationships which may be considered as potential competing interests: 